\title{
BRIDGES AND BARRIERS TO TEACHING ONLINE COLLEGE COURSES: A STUDY OF EXPERIENCED ONLINE FACULTY IN THIRTY- SIX COLLEGES
}

\author{
Peter Shea \\ University at Albany, State University of New York
}

\begin{abstract}
This paper reports on initial findings from a research study of factors that enable and constrain faculty participation in online teaching and learning environments. It is noted that demand for higher education continues to grow in the United States. It is argued that the nature of the higher education student population will likely continue to transform towards a non-traditional profile. These two trends drive an increased demand for alternative routes to a college degree and have fueled dramatic growth in online learning recently. The study identifies faculty acceptance of online teaching as a critical component for future growth to meet this demand and ensure quality. Through analysis of data from 386 faculty teaching online in 36 colleges in a large state university system, the most significant factors that support and undermine motivation to teach online are identified. The top motivator is a more flexible work schedule. The top demotivator is inadequate compensation for perceived greater work than for traditionally delivered courses, especially for online course development, revision, and teaching. However, respondents in this study chose to teach online for a wide variety of reasons many of which were associated with demographic and contextual differences. These distinctions are reviewed in light of their implications for future quality of online education. Additionally, through factor analysis, underlying constructs for online faculty motivations are identified. Finally, recommendations are made for policy, practice, faculty development and future research.
\end{abstract}

\section{KEYWORDS}

Faculty Participation, Motivators, Demotivators, Flexibility, Compensation, Faculty Satisfaction, Policy, Practice, Development

\section{INTRODUCTION}

Demand for higher education continues to grow in the United States. Statistics from the United States Department of Education indicate a 101\% increase in the number of students enrolled in college between 1970 (7.3 million) and 2004 (14.7 million), and enrollment is predicted to continue to rise [1]. According to the National Center for Education statistics, the number of new undergraduates is expected to reach a new high each year from 2007 through 2015 [1]. This may not be surprising in that higher education has long been identified as means of increased social mobility. The monetary value of higher education is fairly clear, for example according to the Census Bureau, over the course of an adult's working life, high school graduates earn an average of \$1.2 million; associate's degree graduates earn approximately $\$ 1.6$ million; and bachelor's degree holders earn about \$2.1 million [2]. Other researchers report that the differential in salaries based on educational attainment has increased over time such that male bachelor degree holders between the ages of 18-35 now earn 94\% more than their higher school graduate counterparts [3]. However, other recent statistics reported by the Department of Education suggest that a 
college degree may primarily allow wage earners to avoid losing ground, noting that workers whose terminal degree was a high school diploma saw a sizable decline in constant dollar wages from 19802004, while college graduates saw modest gains [1].

Beyond salaries college education is also correlated with higher levels of saving, increased personal and professional mobility, improved quality of life among children, better consumer decision making, and more leisure activities [4]. Of course the value of higher education is more than just financial-in a report funded by the Carnegie Foundation, other benefits of higher education included the tendency for college students to become more open-minded, rational, consistent, and less authoritarian. The report found that these characteristics were also communicated to succeeding generations [5]. Other non-monetary returns associated with higher education include reduced crime rates, more and better informed civic participation and improved performance across a broad range of socioeconomic metrics [3]. Finally, higher education can be viewed as unique mechanism for individual intellectual and ethical growth and advancement [6].

While continuing to provide many individual and societal benefits and in the face of expanding enrollments, US higher education has undergone significant changes in recent years. In fact, the composition of US higher education today can be characterized as "non-traditional," where traditional is defined as college attendance immediately following high school with at least some financial support of parents. Roughly 75\% of all college students in 1999-2000 had at least one non-traditional characteristic (age, job status, etc.) [7]. The growth in demand for opportunities that satisfy the needs of non-traditional students track this ongoing and dramatic change in the nature of higher education in the United States. In the last decade distance education has been increasingly employed as a means through which nontraditional students can meet the often competing demands of school, family, and work. Colleges have begun to recognize that non-traditional students require additional modes of access. For example, a majority (56\%) of all two and four-year higher education institutions offered distance learning opportunities in 2001 [8]. Among public institutions that number is far higher, with roughly $90 \%$ of all two and four-year public colleges offering at least some distance learning courses in 2001 [8]. The vast majority of these courses are now offered over the internet- $90 \%$ of colleges offering distance education reported that they offered asynchronous internet-based courses [8]. It is currently estimated that 3.1 million students are enrolled in such courses in the US. Further, it is estimated that growth in enrollments in online higher education will continue to represent the majority of distance education offerings, and with growth rates about ten times that of traditional, classroom-based higher education [9].

Given the longstanding importance of higher education as a means of social mobility and individual improvement, the changing nature of US higher education enrollments from traditional to non-traditional, and the projected growth in distance and online learning as a mechanism to accommodate the needs of the increasing majority of non-traditional college students, it is critical that we examine the factors that support and inhibit the quality of education in this arena. High among such factors are faculty issues, many of which appear to be unaddressed. For example, despite rapidly increasing enrollments in online learning in higher education, a minority (less than one-third) of US Chief Academic Officers believe that their faculty fully accept the value and legitimacy of online education [9]. Clearly the cooperation and acceptance of higher education professors is of central importance to the quality of distance and online education. Given their role as curriculum developers and teachers, college faculty are directly and indirectly responsible for the nature and quality of teaching and learning in higher education. Consequently, understanding issues that enable and constrain successful faculty participation in such new modes of education is crucial. This study therefore examines factors that both support and inhibit faculty motivation for teaching in online environments. 


\section{RELEVANT THEORETICAL FRAMEWORKS}

With approximately 100,000 faculty already involved in online teaching and learning at some level in the US [10], we have reached a stage in which the early adopters are, to a large extent, already involved. We need to know more about the factors that lead less enthusiastic faculty to become engaged in online teaching and learning. A promising conceptual frame is the literature reflecting theoretical models of social change and adoption of innovation in academic settings. Though never coherently applied to the context of online teaching, a number of relevant change and innovation-adoption models exist (e.g. [11, $12,13,14,15,16,17,18,19]$ among others). A component of this research is to identify which of these models is best suited to understanding faculty adoption of online teaching.

A useful direction in this regard is to examine the adoption of online teaching as a process, rather than an event, reflecting early and influential theories such as Stages of Concern Model [13], as well as more recent conceptions such as Concerns Based Adoption Model (CBAM) [16]. The Diffusion of Innovation Model [18] suggests we simultaneously examine characteristics of the individual adopter, the institutional setting, and the technology itself_-steps that have not been taken in research on faculty adoption of online teaching in higher education. In this paper we begin this process by identifying the most commonly expressed concerns stated by faculty with regard to their motivation to teach in online environments. Reflecting the theoretical and research literature in this arena we examine these concerns vis a vis a multitude of potential barriers and affordances including institutional settings, technologies used, faculty demographics, policies, and incentive systems.

\section{REVIEW OF RESEARCH LITERATURE}

The benefits of online education cited by faculty have been well documented (e.g. [20]) and include greater and higher quality interaction with students [21, 22, 23, 24, 25]; increased convenience and flexibility for their teaching and students' learning [22, 26, 27]; better access to student populations and increased access for students to higher education [22]; enhanced knowledge of educational technology [28, 29, 30]; increased opportunities for professional recognition and research [21, 24, 31]; high levels of student learning [21, 30, 32, 33]; greater necessity and opportunity for more systematic design of online instruction and a corollary positive impact on student learning and on classroom teaching [34].

Frequently cited barriers to online teaching include the greater amount of time that is required [22, 27, 30 , $31,35,36]$; compensation issues [22, 24, 28, 29, 37]; intellectual property ownership issues [22, 39, 40]; more work to develop and teach online (which is possibly counterproductive to professional advancement) [36, 37]; technical difficulties [22, 36, 41, 42]; inadequate training, support, and the addition of new roles (e.g., faculty become the helpdesk) [27, 28, 30, 36].

The majority of previous studies have looked at only a fraction of possible motivators and demotivators for online teaching, generally from the perspective of a relatively small sample of professors at a single institution, usually employing a single methodology. While there have been some notable exceptions (e.g. $[43,44,45])$, these broader studies did not focus specifically on the concerns of higher education faculty. The current study does emphasize online college faculty concerns. Our research into faculty motivators and demotivators also employed multiple methodologies, quantitative and qualitative, with a broader sample of faculty from a larger range of institutions and institution types then previous investigations focused on higher education settings. Some of the prior studies and instrumentation served as the basis for development of an online questionnaire and focus group protocols which solicited ratings by faculty of the importance to them of various sources of potential satisfaction or dissatisfaction with teaching online at their university, as explained further below. 
Previously [46], the authors reported on aspects of preliminary qualitative research which included guided discussions with faculty focus groups. The current paper presents quantitative results of a survey of faculty who have taught online from 36 colleges in a nationally recognized program in a single state university system in the Northeastern United States. These results, while also preliminary, are suggestive and may point in promising directions for future research.

\section{METHODS}

To begin to understand the variety of motivators and demotivators for teaching in online environments we surveyed the literature in this area and constructed a pilot survey of these factors. Feedback on the items that were included in the pilot survey was solicited through ninety-minute focus group implemented with six faculty and four doctoral students from three colleges representing a diversity of backgrounds. The group included faculty from a university center, a four-year private liberal arts college, and a private technology college. All of the participants had an expressed interest in the use of technology in education and were members of a forum that met on a regular basis to discuss research in instruction, design, and technology. Details on this field-testing of the survey follow.

Statements about the various advantages and disadvantages of teaching online were listed. For the items describing potential advantages, the pilot group participants were asked to read the statement and, using a seven point likert-type scale, rate the degree to which the advantage affected their motivation to teach online. If the stated advantage increased their desire to teach online they were instructed to choose a higher number $(5,6,7)$. If the advantage did not increase their desire to teach online they were instructed to choose a lower number $(1,2,3)$. Participants in the pilot group were also asked to write notes on aspects of the items that were unclear or confusing, and to suggest motivators and demotivators that were not covered. Feedback from the pilot group was recorded by one of the researchers, and subsequently suggestions regarding item clarity and additional motivators and demotivators were integrated into an expanded and re-formatted version of the original instrument. This version of the instrument was then programmed for online implementation using commercial survey software.

In the fall 2005 semester the survey was administered to faculty teaching in a multi-institutional online program in a single state university system in the Northeastern United States. The researchers worked with the program administrators to solicit respondents. An initial email soliciting participation was sent to all faculty teaching in the program in the fall semester. Follow-up email reminders were sent in two-week intervals three times over a six week period. Five hundred and five questionnaires were electronically collected from faculty teaching in 36 of the 40 institutions in the program that semester, including 119 blank questionnaires. These questionnaires were generated when a respondent followed a link to the survey but did not answer any of the questions, choosing instead to close the survey at that time. These blank surveys were excluded in the analysis. In this initial stage of the research 386 usable responses were therefore gathered, representing a response rate of $61 \%$.

Demographics of the survey respondents are included in Table 1. Demographic information includes the type of college in which the respondent taught, gender, age, academic rank, online teaching experience, number of students in most recent online course, and computer skill level of the respondent. Demographic results suggest a fairly broad representation of faculty from a variety of age groups, college types, and academic ranks. The sample is skewed towards a representation of more experienced online instructors and is in alignment with the population from which the sample is drawn, one characterized by a large proportion of experienced online instructors. However, although this is a fairly large and broad sample, results must be viewed with caution. The response rate suggests that the sample may not be representative of the entire population of online faculty in the program. More importantly, a broad sample of faculty 
who were not teaching online were excluded, and these faculty members undoubtedly have a somewhat different (and more negative) view of motivations and demotivations.

While controversy exists regarding the choice of parametric or non-parametric statistics to analyze ordinal data (e.g. [47]), the more conservative approach is to treat such data as non-parametric in nature. Examination of differences in motivational influences conducted in this paper therefore relies on the use of Pearson chi-squares and standardized adjusted residuals resulting from cross tabular analysis. Standardized adjusted residuals are the observed minus expected value for a table cell divided by an estimate of its standard error. The resulting value is expressed in standard deviation units above or below the group mean. Generally results that indicated differences of more than one standard deviation above or below the mean for an item were considered to be important.

This is exploratory research. We therefore set the significance threshold somewhat high. Three chi-square results are reported here: Pearson chi-square, likelihood ratio and linear-by-linear association. In most cases all three tests were below the .05 level of significance indicative of significant differences, i.e. those unlikely to have occurred randomly or by chance. However, in certain cases we chose to include suggestive results where only one or two tests met that threshold. So, results included here have at least one chi-square test that was at or less than the .05 level of significance. Finally, motivational differences were not considered significant for table cells with expected values less than 5 except in instances where the expected value was for a "neutral" response, i.e. where there was an indication that a difference did exist because very few respondents responded with a neutral choice. These three criteria guided efforts to identify significant motivational differences for online teaching by demographic and contextual factors.

\section{RESEARCH QUESTIONS}

1) What are the advantages of online teaching that recent online instructors report to increase their motivation to teach in online environments? 1a) Do the ranking of these motivators vary based on contextual and/or demographics such as gender, age, faculty rank, online experience or other factors?

2) What are the disadvantages that recent online instructors report as decreasing their motivation to teach in online environments? 2a) Do these demotivators vary based on contextual and/or demographics such as gender, age, faculty rank, online experience or other factors?

3) Do items in the survey used in this study cohere into statistical factors suggesting that they reflect latent constructs interpretable as motivators and demotivators for teaching online that may be useful in future research?

\section{RESULTS}

Research Question 1) What are the factors that recent online instructors report to increase their motivation to teach in online environments?

The results of the survey presented in Table 2 provide an initial answer to this question. As can be seen from these results the motivator rated most highly by respondents included a more flexible work schedule. Following closely were a number of factors that reflect interests in taking on a new challenge, addressing student needs, learning about technology and pedagogy, and providing access to new student populations. Statements that suggested that online education might have monetary or other professional benefits were 
Bridges and Barriers to Teaching Online College Courses:

A Study of Experienced Online Faculty in Thirty-six Colleges

not identified as highly as other possible motivators for teaching online.

2) Do the ranking of these motivators vary based on demographics such as gender, age, faculty rank, online experience or other factors?

Results obtained here suggest that certain demographic and contextual factors are associated with respondents' ranking of the motivators. Differences with regard to factors that motivate faculty were observed by gender, age, academic rank, whether the instructor volunteered or was required to teach online, by computer skill level, and by institutional setting (e.g. whether the instructor taught in a community college, or four-year college).

\section{A. Results: Motivators}

Gender - Two differences were identified with regards to gender. First, female respondents were more likely to report that they were motivated to teach online because online teaching accommodated other life needs (such as child care, transportation, and other family needs). Additionally females identified reduced commuting time or hassle as a motivator more frequently than their male counterparts (Tables 3 and 4).

Age - With regards to age, more "mature" faculty (those 45 or over) were more motivated by opportunities to experiment with new pedagogy then were younger faculty (Table 5). Younger faculty were more motivated (perhaps unrealistically) by opportunities to demonstrate competencies important for tenure or promotion that they believed online teaching provided (Table 6). Younger faculty also reported being motivated by other material incentives that might be available for online teaching (Table 7) and were more likely to report that online teaching might be a condition of employment as a motivating factor (Table 8).

Full-Time/Traditional versus Part-Time/Non Traditional - Motivational differences were also identified by the employment status of the faculty. Part-time/Non-Traditional faculty (lecturers, instructors, and adjuncts) were over represented as a group that identified the capacity of online teaching to accommodate other life needs as a motivator for online teaching, while Full-time/Traditional faculty (assistant, associate, and full professors) were under represented in this category (Table 9). Part-time faculty were also somewhat more motivated by the possibility that online teaching could provide more free time for other professional activities and reduce commuting time or hassle (Tables 10 and 11). Parttime instructors were also more motivated by the opportunity to teach a new subject area and by the possibility that online teaching could promote job security and might be a condition of employment (Tables 12-14).

Voluntariness - Faculty who reported that they volunteered to teach online (as opposed to those reporting that they were asked or required to do so) were more motivated by opportunities to reflect on their classroom teaching, experiment with new kinds of pedagogy, to gain new kinds of knowledge from the experience, and to renew their interest in teaching (Tables 15-18). Respondents who reported that they were asked or required to teach online were more motivated by the fact that online teaching was a condition of employment (Table 19) and by the possibility that additional material incentive might be offered for teaching online (Table 20).

Computer Skill Level - Computer skills played a role in the desire to teach new subject areas through the use of online instruction - those faculty with higher skill levels (perhaps a measure of readiness) 
reported this opportunity to be a greater motivator than less computer savvy faculty (Table 21). Faculty with better computer skills also reported that they were not as motivated by the new challenge that online teaching might represent (Table 22) but were instead more motivated by opportunities to mentor others, especially when compared to faculty who had only average computer skills (Table 23).

Institution Type - Different kinds of institutions were represented in the survey sample, including community colleges, four-year comprehensive colleges, technology colleges, specialized institutions, and university centers. A number of motivational differences were associated with these different institutional settings. For example faculty from community colleges were more likely to report that they had volunteered to teach online rather than being asked or required to do so (Table 24). Given that "voluntariness" is associated with a number of positive outcomes, this may be an important result.

Other institutional differences suggest that faculty at four-year institutions were more likely to feel motivated by the potential of online teaching to accommodate other life needs (such as child care, or other family needs) (Table 25) and to teach a new subject area (Table 26) while faculty at two colleges were more motivated by the belief that online teaching could offer an opportunity to reflect on and improve classroom teaching (Table 27), promote job security (Table 28). Compared to four-year college faculty, community college faculty were particularly unmotivated by the possibility that online teaching might be a condition of their employment (Tables 29).

Demographic and institutional contextual differences were also associated with factors that faculty found particularly demotivating with respect to their choice to teach online. These will be discussed in further detail in the next section.

\section{B. Results: Demotivators}

2) What are the factors that recent online instructors report decrease their motivation to teach in online environments?

Results here again reflect the experience and commitment of the group of online faculty surveyed (Table 30). Very few of the statements describing possible disadvantages of online teaching had the effect of decreasing the desire to teach online very much. Even allowing for this demotivation there were some items that were more important than others. Topping the list of demotivators were issues surrounding compensation for course development, revision, and teaching, and concerns about students' access to the online environment. The compensation issues may be related to the next group of concerns regarding additional time required to develop and teach online courses, which fell just below the concern that campus administration may not recognize the additional effort required to teach online. Given the advanced experience of this population of faculty it may not be surprising that they were not demotivated from online instruction by lack of familiarity with online technology or pedagogy as seen in these results.

2a) Do these demotivators vary based on demographic variables such as age, faculty rank, online experience or other factors?

Differences in factors that undermine motivation to teach online were apparent among the respondents in the following categories: age, academic status, online teaching experience, whether the respondent volunteered or was asked to teach online, computer skill level, and institution type (community colleges v. comprehensive colleges). 
Age - Age of the instructor was associated with concerns about lack of recognition for online teaching in regard to tenure decisions, salary increases, the possibility that online teaching may not be valued by campus administrators, and concerns that others might feel online courses were of inferior quality compared to traditional courses. Perhaps understandably, younger faculty (defined here as those under 45) were more demotivated from online teaching (Tables 31-34) by these concerns than older faculty (over age 45).

Academic Status, Tenure - Faculty tenure status appears to be related to factors that undermine motivation to teach online. Faculty who were either non-tenure track or untenured were over represented in the group that reported that their desire to teach online was decreased by inadequate compensation for course development, online teaching, and online course revision. Tenured faculty (associate and full professors) were under represented in these categories (Tables 35-37). Traditional faculty (assistant, associate and full professors) were more demotivated by the perception that online teaching was more time consuming than were faculty who were part-time or non traditional, defined as adjuncts, instructors and teaching assistants (Table 38).

Online Teaching Experience - The number of times an instructor had taught online was associated with the relative importance of the demotivators. Less experienced online teachers (those who had taught one or two times) were over represented in the group that reported that absence of face-to-face interaction decreased their desire to teach online (Table 39). Faculty who had taught three or more times were under represented in this category. Similarly, less experienced instructors were also more put off by their unfamiliarity with effective online pedagogy, lack of opportunity to observe online teaching before engaging in it, lack of opportunity to experiment with the technologies of online teaching, and inadequate time to learn about online teaching (Tables 40-43). Less experienced instructors were also over represented among those reporting that compensation issues (for course development and teaching) undermined their desire to teach online. More experienced instructors were under represented in these categories (Tables 44 and 45). Finally, less experienced instructors appeared more concerned that offering online education might reduce the reputation of their institution, while more experienced instructors were under represented among respondents who identified this as a factor that reduced their desire to teach online (Table 46).

"Voluntariness" also played a role with regard to the factors that demotivated faculty from teaching online. Faculty who felt they had been required to teach online were more demotivated by perceptions that the technology was confusing, the absence of face-to-face interaction, perceptions that students might lack access, lack of opportunity to experiment with technology, inadequate time to learn about online teaching and inadequate time to develop online courses (Tables 47-52). Non-volunteers also felt more put off from online teaching by concerns that it might not be recognized by campus administration and by the perception that online courses might be of inferior quality to classroom-based courses (Tables 53 and 54).

Institutional Differences were again evident when analyzing demotivating factors for online teaching. Faculty at comprehensive colleges (four-year institutions) were more concerned about lack of recognition of online teaching with regards to tenure decisions than were faculty at two year colleges (Table 55). Faculty at four-year institutions were also more put off by the perception that online teaching can be confusing and that there is inadequate time to revise online courses (Tables 56 and 57).

Computer Skill Level was associated with demotivational aspects of online teaching. Faculty who reported that they had higher computer skill levels were over-represented in the categories of respondents who reported that inadequate compensation and lack of recognition from the campus administration 
Bridges and Barriers to Teaching Online College Courses:

A Study of Experienced Online Faculty in Thirty-six Colleges

decreased their desire to teach online while those with lower computer skill levels were underrepresented in these categories (Table 58 and 59).

\section{FACTOR STRUCTURES FOR MOTIVATORS AND DEMOTIVATORS}

3) Do items in the survey used in this study cohere into statistical factors suggesting that they reflect latent constructs interpretable as reliable motivators and demotivators for teaching online that may be useful in future research?

To understand whether the items in the survey measure latent constructs that can be interpreted as motivators and demotivators for online teaching, we conducted a factor analysis. First, a maximum likelihood estimate with direct oblique rotation was used to test the factor construct of the items that reflected advantages or presumed motivators for teaching online. The inter-correlation coefficients for the items were greater than .30 and the KMO sampling adequacy (.90) and Bartlett's test of sphericity (chisquare is 3310.91, $\mathrm{p}<.001$ ) supported the applicability of conducting factor analysis. For the motivators, five factors were extracted with eigenvalues greater than 1 . Using this model, $64.6 \%$ of the total variance could be explained by these factors. The overall reliability (Chronbach's alpha) was .94 with individual reliability measures between .78 and .91 . This analysis led to an interpretable factor structure and we labeled the factors "learning”, "profession”, "flexibility”, “access” and "novelty”, reflecting the nature of the items and concerns that each contained (Table 62).

For the demotivators the same procedure was followed. The inter-correlation coefficients for the items were greater than .30 and the KMO sampling adequacy (.91) and Bartlett's test of sphericity (chi-square is 4498.81, $\mathrm{p}<.001$ ) again supported the applicability of conducting factor analysis. Five factors were extracted with eigenvalue greater than 1 . In all, $71.5 \%$ of the total variance could be explained. The overall reliability (Chronbach's alpha) was .96 with individual reliability measures between .83 and .93. These factors were labeled "compensation”, "reputation”, “complexity”, "promotion” and "technology", reflecting the nature of the items and concerns that each contained (Table 63).

\section{DISCUSSION}

The results presented here advance our understanding of the issues that support and undermine faculty willingness to teach in online environments and thus our ability to make higher education more accessible through this modality. Given the increased demand and historic benefits of higher education, coupled with the changing nature of the college student population, providing alternative options for access to college will continue to be a critical strategy to satisfy societal needs. Gaining insight into the factors that enable and constrain faculty acceptance and ongoing participation in the e-learning enterprise is a crucial piece of the puzzle. In this section we will first discuss motivators and then demotivators, reflecting results presented in the previous section.

\section{A. Motivators}

From these results we see that faculty in the state university systems studied here value online teaching for a number or reasons. "Flexibility" is among the most appealing advantages reported by this group of faculty who are experienced with online teaching. In light of this finding, it seems sensible to highlight and to preserve this aspect of the online teaching experience as fully as possible. Helping other faculty to understand that online teaching can provide greater control over their work life (as reported by these 
experienced online instructors) will be beneficial in promoting online teaching as a method of increasing access to higher education. Taking care that flexibility and convenience do not take such a high priority that they begin to undermine the quality of the experience for students is a prime concern. Faculty development activities need to articulate both of these possibilities, and encourage a balanced approach. While online teaching can promote flexibility and convenience (for both students and faculty) it should not take precedence to the extent that quality suffers. Helping faculty to establish and maintain regular schedules for teaching and managing online courses is crucial to avoiding both the potential for overwhelming levels of interaction and for avoiding the potential problems associated with too little interaction. Providing direction for policies with regard to expected and reasonable levels of interaction with and between faculty and students is also useful in this regard.

Faculty respondents were also motivated by the opportunity to gain new pedagogical knowledge through online teaching, including opportunities to experiment with new pedagogy, reflect on classroom teaching, and gain new understanding of assessment issues. Respondents also reported being motivated by opportunities to learn about new technology and take on a new challenge more generally. In order to continue to attract new faculty to online teaching these opportunities for learning should also be highlighted in faculty development and other promotional efforts.

Faculty in this study were also concerned about their students' welfare and with increasing access to higher education (and their institutions specifically) through online teaching. Opportunities to reach new students with different cultural backgrounds, more mature students, and students in different geographical locations all appealed quite highly to respondents. Helping other faculty to understand that experienced colleagues report that online teaching can help achieve this highly rated objective will also be valuable in achieving more committed participation to online teaching.

Statements describing possible advantages that reflect either enhanced compensation or professional advancement opportunities as a result of online teaching were rated lower by respondents than other potential advantages. It appears that either faculty are not motivated by such possibilities or, given the results with regard to the demotivators, online teaching does not offer these possibilities. The latter seems the more likely of the two possibilities. Not only do respondents rate these potential advantages as less motivating, but fewer respondents chose to offer a rating of any kind for these potential motivators, choosing instead the N/A option. From these results it appears that compensation issues can undermine desire to teach online, especially given the disadvantages that were identified.

Contextual Differences - Some of the most interesting results of the study are the demographic and contextual factors that seem to play a role in the choice to teach online. If we seek to understand why higher education faculty may accept or reject online instruction, it is critical that we recognize the complexity of the issue. The theme of quality in online teaching and learning has a long history and lineage dating to the earliest efforts in distance education (e.g. [48]). Results presented here suggest that the choice to participate in online teaching is influenced by many factors. Engaging faculty as stewards of quality in this enterprise requires that we understand why they are likely to accept or reject this role.

Gender - Results hinted that female faculty may be more attracted to online teaching for the flexibility and convenience it affords. These results support and extend previous research into the experience of women as learners in online education (e.g. [49]) documenting its appeal as a mechanism to cope with the myriad roles women play and personal and professional challenges they confront. Our results suggest that these advantages may appeal to female online instructors as well as online learners. 
Age - A number of differences in ranking of motivators were associated with age. These mirror other differences that were associated with academic status and experience with online teaching. Results suggest that younger faculty, perhaps naturally, appear more concerned with opportunities to advance in their careers and seem to be pinning some of their hopes to advantageous experiences gained through online course development and teaching to accomplish this goal. Much of the culture of higher education is incompatible with these hopes; however, new faculty in certain institutional contexts are warned that such activities may actually be detrimental, taking away from more important responsibilities such as research and publication. It seems clear that if younger faculty are to play a role in the furtherance of quality in online education, reward structures need to be aligned with that objective.

Employment Status - Other motivational differences were associated with employment structures. Full and part-time faculty ranked motivators differently. It is no secret that part-time instructors play a significant role in the academic offerings of many institutions of higher education, and are thus, by default, stewards of the quality of online education. Results suggest that part-time instructors are more appreciative of the benefits of flexibility associated with online teaching, ranking highly its capacity to accommodate other life needs, provide free time for other activities and reduce commuting time or hassle. Flexibility and convenience are well known advantages of online education, but again we need to take care that these attributes do not take precedence over pedagogical quality, learner engagement, and innovation. Flexibility and convenience can become ends rather than means and given the large and increasing number of part-time faculty involved in higher education, both online and in the classroom, we need to be aware of the potential pitfalls. That part-time faculty were over represented as a group that identified flexibility and convenience as a primary motivator may be a cause for concern in this regard.

Voluntariness and Institutional Context - Faculty who taught in two year colleges were more likely to volunteer to teach online than were faculty employed by four year colleges. It appears likely that cultural distinctions in these institution types favor online teaching for community college faculty. Given that voluntariness is associated with a range of other positive variables, this result may account for the relative over representation of community colleges among the ranks of online providers. Volunteers (and thus community college faculty) were also over-represented among faculty who ranked pedagogical value of online course development as a motivator, highlighting opportunities to reflect on classroom instruction, experiment with new forms of pedagogy, gain new knowledge, and renew interest in teaching. Nonvolunteers associated the potential for material incentives with their desire to teach online. Four year college faculty were over represented among those who gave high marks to flexibility and convenience indicators such as benefits associated with child care or other family needs. Again it must be stressed that such convenience benefits need to be balanced against pedagogical quality issues. Given that voluntariness appears associated with such a broad range of factors likely to increase quality, these results suggest we need to work to ensure that faculty feel ownership over the decision to teach online.

Computer Skill Level - Faculty with higher reported computing skills appeared less motivated by the notion that online teaching might be a new challenge and more motivated to act as a mentor to others. Providing such opportunities through professional development programs has some obvious potential benefits in terms of engaging additional faculty in the quest for quality. Better computing skills may also be a prerequisite to the desire to teach in a new subject area online; respondents with lower computer skills did not identify this possibility as motivating as those with higher abilities. It seems likely that the struggle associated with mastering the technical aspects of online teaching may be a sufficient challenge without adding new subject matter into the mix. A potential lesson for faculty development professionals_-keep it simple, especially with computer novices.

We turn now to a discussion of the demotivators. 
Bridges and Barriers to Teaching Online College Courses:

A Study of Experienced Online Faculty in Thirty-six Colleges

\section{B. Demotivators}

The results on demotivators for teaching online are instructive in a number of ways. First, for this group of experienced online teachers, there were very few strongly demotivating factors - respondents simply did not weigh the effects of the disadvantages very heavily against their motivations to teach online. The disadvantages were seen as only somewhat demotivating; the highest mean score was 4.15 on a scale of 1-7 with 7 indicating the highest level of demotivation. Given the relatively consistent finding that faculty report online teaching takes more time and effort than classroom teaching, it may not be surprising that our respondents felt that inadequate compensation was their top demotivator. In fact, respondents identified inadequate compensation for course development, revision, and teaching as the most demotivating disadvantages associated with online teaching.

We felt it useful to again look at subgroups to determine where demotivational differences might be seen. We found distinctions based on age, academic status, online teaching experience, voluntariness, institution type, and computer skill level. Again the theme of faculty stewardship of online educational quality is a useful lens for framing the discussion of these differences. The results suggesting that younger faculty were more demotivated by concerns around professional advancement is cause for concern. If the goals of increasing access and ensuring quality of online higher education are to be realized it is crucial that younger faculty not be dissuaded by poor alignment between these goals and institutional reward structures. Overrepresentation of younger faculty among the group that rated a lack of recognition of online teaching by campus administration in general, and with regard to tenure decisions and salary increases specifically suggests such a misalignment exists for these instructors.

Also potential causes for concern are the differences in ranking of demotivators by academic status. Nontenure (part-time) and untenured (assistant professors) were over represented among the group that identified compensation issues as undermining their desire to teach online. Results reflecting the undermining impact of inadequate remuneration for online course development, teaching, and revision, especially among a more dedicated cohort of online educators such as found in our sample, does not bode well for increased adoption of online teaching among less enthusiastic faculty. Again, given the increasing dependence on part-time faculty in higher education (both online and in the classroom) and the need to involve younger, pre-tenured faculty as stewards of online educational quality, these results raise the need for a discussion of policies that address these concerns. Results suggesting that traditional faculty (assistant, associate, and full professors) were more demotivated by concerns relating to the time consuming nature of online education may also be of concern. Time is a proxy for priority. These results reflect the perennial concern [48] that online learning may be marginalized from the core cultural practitioners, i.e. traditional faculty, and reside at the periphery of college life with the stigmatizing impact that such marginalization implies. If the goals of increased access and quality are to be achieved we need policies that enable full-time faculty to make online education a higher priority. Results suggesting that faculty at four-year colleges were more concerned about lack of recognition for online teaching in tenure decisions is further evidence of potential exclusion of online education from the mainstream of academia. Again, an examination of institutional reward structures relative to their impact on faculty priority setting would be a reasonable starting point for the discussion.

A number of demotivational distinctions related to online teaching experience suggest the need for ongoing professional development. That less experienced online teachers may be more dissuaded by their unfamiliarity with effective online pedagogy, absence of face-to-face interaction, lack of opportunity to observe online teaching before trying it, lack of opportunity to experiment with online technology before adopting it, and inadequate time to learn about online teaching suggests that future growth and quality is contingent on the availability of training. As noted above such professional development needs to be coupled with policies that make online education a recognized institutional priority. Results suggesting 
that faculty with better computing skills were more motivated by opportunities to mentor others than by more general new challenges may be useful in this regard. Leveraging the assistance of such more able peers represents one promising strategy for helping less experienced online instructors to confront the challenges they identified as demotivating.

\section{Factor Analysis}

The factor analysis presented here suggests that the data has an interpretable factor structure. Relatively clear factors emerged, reflecting faculty concerns compatible with previous empirical and conceptual research in this area. These results suggest that motivational items reflect latent constructs important to understanding bridges and barriers to online teaching. Bridges include faculty learning, professional advancement opportunities, flexibility and convenience, provision of access, and benefits associated with novelty and innovation. Barriers reflect issues associated with inadequate compensation relative to time investment, lack of recognition for and negative reputation of online teaching, complexities of technology and online pedagogy, and reward structure misalignments with online teaching. We encourage other researchers to use this instrument in future investigations to provide additional checks of validity and reliability regarding bridges and barriers to online teaching.

\section{LIMITATIONS AND FUTURE RESEARCH}

As an exploratory study the research approach utilized here sought to generate questions as well as answers. While it is useful to attempt to generate new hypotheses, examination of so many individual variables can result in Type I errors and thus spurious findings. Therefore these results need to be replicated through additional research. This is a preliminary study of a relatively small range of faculty (fewer than 400) who are experienced in teaching online, at 36 campuses that are part of the same state university system. We need to have data on faculty from different settings and in different states in order to determine the extent to which motivators and demotivators are shaped by the other contexts, or to which they are similarly perceived in terms of their importance at all types of institutions. We also need a larger and more nationally representative set of responses in order to validate the generalizability of the factor structures observed for these data. The participants in this study appeared to be highly committed to online teaching. Therefore, most importantly, we need to study faculty who have rejected or not had an opportunity thus far to teach online in order to compare their ratings of motivating and demotivating aspects of teaching online with those of more experienced online instructors.

\section{ACKNOWLEDGEMENTS}

This research was partially supported in part by a grant from the Alfred P. Sloan Foundation, for which Starr Roxanne Hiltz is a co-PI. The author is grateful for her contributions to this paper. The author also wishes to thank the Office of SUNY Learning Environments for its direct support of this research and to express gratitude to the Director of SUNY Learning Network and the SLN team. SUNY Learning Environments is an office of the Provost and Vice-chancellor of the State University of New York. Finally special thanks to Chun Sau Li for her assistance with statistical factor analysis.

\section{ABOUT THE AUTHOR}

Peter Shea, former director of the SUNY Learning Network, has a joint appointment with the Department of Educational Theory and Practice and the College of Computing and Information at the University at Albany, State University of New York. He is currently principal investigator on a Sloan Foundation funded study of faculty motivation for teaching online. He was also recently awarded a grant 
by Sloan to implement a series of blended academic programs in the School of Education and other units at the University at Albany, State University of New York. He is author of many articles on student and faculty experiences in online education, and co-author of "The Successful Distance Learning Student."

\section{REFERENCES}

1. The Condition of Education 2006. In: U.S. Department of Education, National Center for Education Statistics, NCES 2006-071, Washington, DC: U.S. Government Printing Office, 2006. http://nces.ed.gov/pubs2006/2006071.pdf.

2. Day, J. C. and E. C. Newburger. The Big Payoff: Educational Attainment and Synthetic Estimates of Work-Life Earnings. (Current Population Reports, Special Studies, P23-210). Washington, DC: Commerce Dept., Economics and Statistics Administration, Census Bureau, 2002. http://www.census.gov/prod/2002pubs/p23-210.pdf.

3. Hill, K., D. Hoffman and R. Rex. The value of higher education: Individual and societal benefits, 2005. http://wpcarey.asu.edu/seid/upload/Value\%20Full\%20Report final october\%202005a.pdf.

4. Institute for Higher Education Policy. Reaping the Benefits: Defining the Public and Private Value of Going to College. The New Millennium Project on Higher Education Costs, Pricing, and Productivity, Washington, DC, 1998.

5. Rowley, L. L. and S. Hurtado. The Non-Monetary Benefits of an Undergraduate Education. University of Michigan: Center for the Study of Higher and Postsecondary Education, 2002.

6. Perry, W. Forms of Ethical and Intellectual Development in the College Years. San Francisco: Jossey-Bass, 1999.

7. Choy, S. Nontraditional Undergraduates. In: U.S. Department of Education, National Center for Education Statistics, NCES 2002-012, Washington, DC: U.S. Government Printing Office, 2002.

8. Distance Education at Degree-Granting Postsecondary Institutions: 2000-2001. U.S. Department of Education, National Center for Education Statistics, NCES 2003-017, Washington, DC: U.S. Government Printing Office, 2003.

9. Allen, I. E. and J. Seaman. Growing by Degrees: Online Education in the United States. Needham, MA: Sloan-C, 2005.

10. Bourne, J. Introductory remarks. Proceeding of the Sloan-C Summer Research Workshop. Needham, MA:Sloan-C, 2005.

11. Anderson, S. E. Understanding teacher change: Revisiting the concerns-based adoption model. Curriculum Inquiry 27(3): 331-367, 1997.

12. Cheung, D., J. Nattie and N. Davis. Reexamining the stages of concern questionnaire: A test of alternative models. The Journal of Educational Research, 94: 226-236, 2001.

13. Davis, F., R. Bagozzi and P. Warsaw. User acceptance of computer technology: A comparison of two theoretical models. Management Science 35(8): 982-1003, 1989.

14. Fuller, F. F. Concerns of teachers: A developmental conceptualization. American Education Research Journal 6: 207-226, 1969.

15. Hall, G. E., R. C. Wallace and W. A. Dossett. A Developmental Conceptualization of the Adoption Process Within Educational Institutions. Austin, TX: Research and Development Center for Teacher Education, The University of Texas, 1973.

16. Hall, G. E. and S. M. Hord. Change in Schools. Albany, NY: State University of New York Press, 1987.

17. Hall, G. E. and S. M. Hord. Implementing Change: Patterns, Principles, and Potholes. Needham Heights, MA: Allyn \& Bacon, 2001.

18. Rogers, E. M. Diffusions of Innovations, $1^{\text {st }}$ Ed. New York: Free Press, 1963.

19. Rogers, E. M. Diffusions of Innovations, $5^{\text {th }}$ Ed. New York: Free Press, 2003. 
Bridges and Barriers to Teaching Online College Courses: A Study of Experienced Online Faculty in Thirty-six Colleges

20. Dziuban, C., P. Shea and J. Arbaugh. Faculty roles and satisfaction in ALNs. In: S. R. Hiltz and R. Goldman (Eds.), Learning Together Online: Research on Asynchronous Learning Networks, 169190. Mahway, NJ: Lawrence Elrbaum Associates, 2005.

21. Kashy, E., M. Thoennessen, G. Albertelli and Y. Tsai. Implementing a large on-campus ALN: Faculty perspective. Journal of Asynchronous Learning Networks 4(3): 231-244, 2000.

22. Hartman, J., C. Dzuiban and P. Moskal. Faculty satisfaction in ALNs: A dependent or independent variable. Journal of Asynchronous Learning Networks 4(3): 2000. http://www.sloanc.org/publications/jaln/v4n3/v4n3_hartman.asp.

23. National Education Association. Focus on distance education. Update 7(2): March 2001, Washington, DC. http://www2.nea.org/he/heupdate/images/vol7no2.pdf.

24. Shea, P., E. Fredericksen, A. Pickett, W. Pelz and K. Swan. Measures of learning effectiveness in the SUNY Learning Network. In J. Bourne and J. C. Moore (Eds.), Online Education, Volume 2: Learning Effectiveness, Faculty Satisfaction, and Cost Effectiveness, 7-31. Needham, MA: Sloan-C, 2001.

25. Smith, L. Faculty satisfaction in LEEP. A web-based graduate degree program in library and information science. In J. Bourne and J. C. Moore (Eds.), Online Education, Volume 2: Learning Effectiveness, Faculty Satisfaction, and Cost Effectiveness, 87-108. Needham, MA: Sloan-C, 2001.

26. Swan, K., P. Shea, E. Fredericksen, A. Pickett, W. Pelz and G. Maher. Building knowledge building communities: Consistency, contact and communication in the virtual classroom. Journal of Educational Computing Research 23(4): 359-383, 2000.

27. Arbaugh, J. B. Virtual classroom characteristics and student satisfaction in internet-based MBA courses. Journal of Management Education 24: 32-54, 2000.

28. Hartman, J. L. and B. Truman-Davis. Factors relating to the satisfaction of faculty teaching online courses at the University of Central Florida. In J. Bourne and J. C. Moore (Eds.), Online Education, Volume 2: Learning Effectiveness, Faculty Satisfaction, and Cost Effectiveness. Needham, MA: Sloan-C, 2001.

29. Fredericksen, E., A. Pickett, W. Pelz, K. Swan and P. Shea. Factors influencing faculty satisfaction with asynchronous teaching and learning in the SUNY Learning Network. Journal of Asynchronous Learning Networks 4(3): 245-278, 2000.

30. Rockwell, K., J. Schauer, S. M. Fritz and D. B. Marx. Incentives and obstacles influencing higher education faculty and administrators to teach. Online Journal of Distance Learning Administration 2(4): 1999. http://www.westga.edu/ distance/rockwell24.html.

31. Thompson, M. Faculty satisfaction in Penn States World Campus. In J. Bourne and J. C. Moore (Eds.), Online Education, Volume 2: Learning Effectiveness, Faculty Satisfaction, and Cost Effectiveness, 129-144. Needham, MA: Sloan-C, 2001.

32. Hislop, G. and M. Atwood. ALN teaching as routine faculty workload. Journal of Asynchronous Learning Networks 4(3): 2000. http://www.sloan-c.org/publications/jaln/v4n3/v4n3 hislop.asp.

33. National Education Association. A survey of traditional and distance learning higher education members. Washington DC, 2000.

34. Shea, P., W. Pelz, E. Fredericksen and A, Pickett. Online teaching as a catalyst for classroombased instructional transformation. In J. Bourne and J. C. Moore (Eds.), Elements of Quality Online Education, 103-126. Needham, MA: Sloan-C, 2002.

35. Shea, P., E. Fredericksen, A. Pickett and W. Pelz. Faculty development, student satisfaction, and reported learning in the SUNY Learning Network. In T. Duffy and J. Kirkley (Eds.), Learnercentered Theory and Practice in Distance Education, 343-377. Mahway, NJ: Lawrence Elrbaum Associates, 2004.

36. Clay, M. Faculty attitudes toward distance education at the State University of West Georgia. University of West Georgia Distance Learning Report, 1999. http://www.westga.edu / distance/attitudes.html. 
37. Schifter, C. C. Faculty participation in asynchronous learning networks: A case study of motivating and inhibiting factors. Journal of Asynchronous Learning Networks 4(1): 15-22, 2000. http://www.sloan-c.org/publications/jaln/v4n1/v4n1 schifter.asp.

38. Betts, K. S. Factors influencing faculty participation in distance education in postsecondary education in the United States: An institutional study. Doctoral dissertation, The George Washington University, Dissertation Abstracts International: UMI, 1998.

39. Wolcott, L.L. Tenure, promotion, and distance education: Examining the culture of faculty rewards. The American Journal of Distance Education 11(2): 3-18, 1997.

40. Twigg, C. Who Owns Online Courses and Course Materials? Intellectual Property Policies for a New Learning Environment, 2001. http://www.thencat.org/Monographs/Mono2.pdf.

41. Werry, C. and M. Mowbray. Online Communities: Commerce Community Action, and the Virtual University. Upper Saddle River, NJ: Prentice Hall, 2001.

42. Chizmar, J. F. and D. B. Williams. What Do Faculty Want? EDUCAUSE Quarterly 24(1): 18-24, 2001.

43. Muilenburg, L. Y. and Z. L. Berge. Barriers to distance education: A factor-analytic study. The American Journal of Distance Education 15(2): 7-22, 2001.

44. Berge, Z. L. and L. Y. Muilenburg. Obstacles faced at various stages of capability regarding distance education in institutions of higher learning. Tech Trends 46(4): 40-45, 2001.

45. Berge, Z. L., L. Y. Muilenburg and J. V. Haneghan. Barriers to distance education and training: Survey results. The Quarterly Review of Distance Education 3(4): 409-418, 2002.

46. Hiltz, S.R., Kim, E. and Shea, P. Faculty Motivators and Demotivators for Teaching Online: Results of Focus Group Interviews at One University. Proceedings of the 40th Annual Hawaii International Conference on System Sciences, 2006.

47. Velleman, P. and L. Wilkinson. Nominal, ordinal, interval, and ratio typologies are misleading. The American Statistician 47(1): 65-72, 1993.

48. Larreamendy-Joerns, J. and G. Leinhardt. Going the distance with online education. Review of Educational Research 76(4): 567-605, 2006.

49. Kramarae, C. The third shift - women learning online. American Association of University Women, 2001.

\section{APPENDIX: TABLES AND TESTS}

Table 1: Demographic Data and Teaching Experience $(\mathrm{N}=386)$

\begin{tabular}{|c|c|c|c|}
\hline & Frequency & Percent & Valid Percent \\
\hline Institution & & & \\
\hline Community College & 204 & 52.8 & 55.7 \\
\hline University Center & 19 & 4.9 & 5.2 \\
\hline University College & 104 & 26.9 & 28.4 \\
\hline College of Technology & 12 & 3.1 & 3.3 \\
\hline Specialized College & 17 & 4.4 & 4.6 \\
\hline Other & 10 & 2.6 & 2.7 \\
\hline Chose not to answer & 11 & 2.8 & \\
\hline Blank (no answer) & 9 & 2.3 & \\
\hline Gender & & & 47.0 \\
\hline Male & 174 & 45.1 & 53.0 \\
\hline Female & 196 & 50.8 & \\
\hline Chose not to answer & 12 & 3.1 & \\
\hline
\end{tabular}


Bridges and Barriers to Teaching Online College Courses:

A Study of Experienced Online Faculty in Thirty-six Colleges

\begin{tabular}{|c|c|c|c|}
\hline Blank (no answer) & 4 & 1.0 & \\
\hline \multicolumn{4}{|l|}{ Age } \\
\hline $20-24$ & 2 & .5 & .6 \\
\hline $25-29$ & 12 & 3.1 & 3.4 \\
\hline $30-34$ & 24 & 6.2 & 6.8 \\
\hline $35-39$ & 37 & 9.6 & 10.5 \\
\hline $40-44$ & 33 & 8.5 & 9.4 \\
\hline $45-49$ & 41 & 10.6 & 11.6 \\
\hline $50-54$ & 66 & 17.1 & 18.8 \\
\hline $55-59$ & 64 & 16.6 & 18.2 \\
\hline $60-64$ & 42 & 10.9 & 11.9 \\
\hline 65 or older & 31 & 8.0 & 8.8 \\
\hline Chose not to answer & 30 & 7.8 & \\
\hline Blank (no answer) & 4 & 1.0 & \\
\hline \multicolumn{4}{|l|}{ Academic Category } \\
\hline Teaching Assistant & 6 & 1.6 & 1.6 \\
\hline Instructor & 57 & 14.8 & 15.5 \\
\hline Lecturer & 10 & 2.6 & 2.7 \\
\hline Adjunct Professor & 128 & 33.2 & 34.8 \\
\hline Assistant Professor & 55 & 14.2 & 14.9 \\
\hline Associate Professor & 46 & 11.9 & 12.5 \\
\hline Full Professor & 66 & 17.1 & 17.9 \\
\hline Chose not to answer & 14 & 3.6 & \\
\hline Blank (no answer) & 4 & 1.0 & \\
\hline \multicolumn{4}{|l|}{ Times teaching } \\
\hline First time & 66 & 17.1 & 18.1 \\
\hline Second time & 30 & 7.8 & 8.2 \\
\hline Third time & 52 & 13.5 & 14.2 \\
\hline Fourth time & 42 & 10.9 & 11.5 \\
\hline Fifth time & 34 & 8.8 & 9.3 \\
\hline More than five times. & 141 & 36.5 & 38.6 \\
\hline Chose not to answer & 8 & 2.1 & \\
\hline Blank (no answer) & 13 & 3.4 & \\
\hline \multicolumn{4}{|c|}{ Number of Students in Course } \\
\hline $1-10$ & 37 & 9.6 & 9.9 \\
\hline $11-20$ & 186 & 48.2 & 49.9 \\
\hline $21-30$ & 103 & 26.7 & 27.6 \\
\hline $31-40$ & 23 & 6.0 & 6.2 \\
\hline $41-50$ & 15 & 3.9 & 4.0 \\
\hline More than 50 & 2 & .5 & .5 \\
\hline More than 100 & 7 & 1.8 & 1.9 \\
\hline Blank (no answer) & 13 & 3.4 & \\
\hline
\end{tabular}


Bridges and Barriers to Teaching Online College Courses:

A Study of Experienced Online Faculty in Thirty-six Colleges

\begin{tabular}{|c|c|c|c|}
\hline Computer Skill & & & \\
\hline Low & 29 & 7.5 & 7.9 \\
\hline Medium & 168 & 43.5 & 45.9 \\
\hline High & 169 & 43.8 & 46.2 \\
\hline Chose not to answer & 7 & 1.8 & \\
\hline Blank (no answer) & 13 & 3.4 & \\
\hline
\end{tabular}

Table 2: Descriptive Statistics for Motivators to Teach Online

\begin{tabular}{|c|c|c|c|}
\hline Teaching online can provide... & $\mathrm{N}$ & Mean & SD \\
\hline 14. .... more flexible work schedule & 346 & 6.08 & 1.439 \\
\hline 23. ... an opportunity to "stretch," - take on a new challenge & 351 & 5.87 & 1.359 \\
\hline 37. Students may want online courses & 347 & 5.76 & 1.540 \\
\hline 24. ... an opportunity to learn new technology & 349 & 5.74 & 1.513 \\
\hline $\begin{array}{l}20 . . . \text { an opportunity to gain new knowledge, skills, and insights about my } \\
\text { teaching }\end{array}$ & 350 & 5.72 & 1.414 \\
\hline 19. ... an opportunity to experiment with new pedagogical approaches & 348 & 5.70 & 1.333 \\
\hline 27. ... an opportunity to reach students in different geographical locations & 347 & 5.69 & 1.685 \\
\hline $\begin{array}{l}\text { 29. ... an opportunity to reach students at different stages of their learning lives } \\
\text { (e.g. more mature/experienced, older, younger, etc.) }\end{array}$ & 343 & 5.68 & 1.748 \\
\hline 28. ... an opportunity to reach students with different cultural backgrounds & 337 & 5.55 & 1.787 \\
\hline 18. ... an opportunity to reflect upon and rethink classroom teaching & 341 & 5.51 & 1.564 \\
\hline 21. ... an opportunity to experiment with alternative means of assessment & 344 & 5.42 & 1.587 \\
\hline $\begin{array}{l}15 . . . \text { accommodate other life needs (child care, transportation, other family } \\
\text { needs) }\end{array}$ & 330 & 5.41 & 1.930 \\
\hline 17. ...reduce commuting time, or hassle & 326 & 5.30 & 2.100 \\
\hline 25. ... to renew interest in teaching (overcome staleness, apathy) & 331 & 5.01 & 1.897 \\
\hline 22. ... a higher level of interaction with my students & 344 & 4.82 & 1.961 \\
\hline $\begin{array}{l}\text { 31. Online courses/programs can allow an institution to maintain or increase } \\
\text { enrollment/revenue and therefore promotes "job security." }\end{array}$ & 320 & 4.80 & 2.017 \\
\hline $\begin{array}{l}\text { 16. ... provide more free time for other professional activities (e.g. attend } \\
\text { conferences, consulting, etc) }\end{array}$ & 334 & 4.72 & 2.175 \\
\hline 33. ...become a mentor or to assist others to learn about online teaching. & 332 & 4.63 & 1.912 \\
\hline 36. Colleagues may refer to online teaching in a positive way. & 336 & 4.63 & 1.764 \\
\hline $\begin{array}{l}\text { 32. ...participate in a collaborative professional development activity (e.g. training) } \\
\text { which enhances relationship with peers. }\end{array}$ & 335 & 4.44 & 1.933 \\
\hline 26. ... to teach a new subject area & 301 & 4.41 & 2.242 \\
\hline $\begin{array}{l}\text { 30. Teaching online can provide an additional opportunity to demonstrate } \\
\text { competencies important for tenure and promotion }\end{array}$ & 297 & 4.25 & 2.148 \\
\hline 35. Other material incentives may be available for online course development & 266 & 4.08 & 2.243 \\
\hline $\begin{array}{l}\text { 34. Teaching online may be a condition of your employment (hired to teach } \\
\text { online) }\end{array}$ & 240 & 3.68 & 2.327 \\
\hline
\end{tabular}

Note: Range $=1$ (not a motivator) to 7 (strongest motivator) 
Bridges and Barriers to Teaching Online College Courses: A Study of Experienced Online Faculty in Thirty-six Colleges

Table 3: Motivator Differences by Gender: “Online teaching can accommodate other life needs such as child care, transportation, etc."

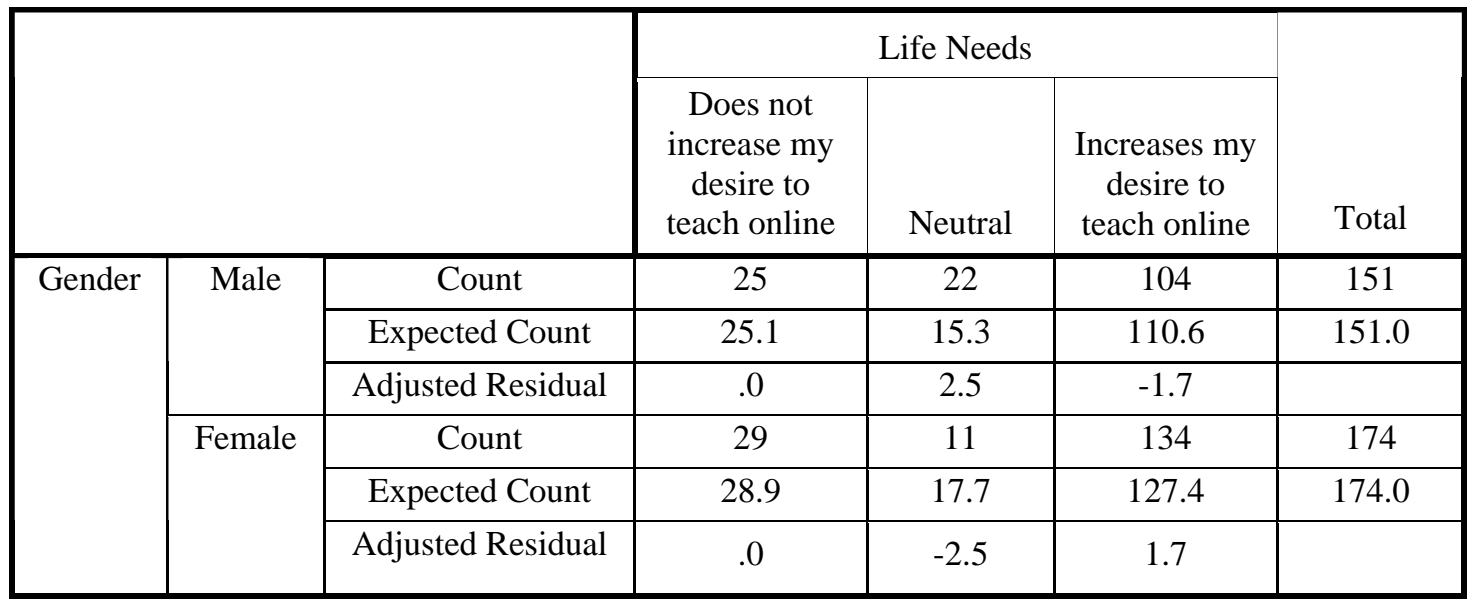

\section{Chi-Square Tests}

\begin{tabular}{|c|c|c|c|}
\hline & Value & $\mathrm{df}$ & $\begin{array}{c}\text { Asymp. Sig. } \\
\text { (2-sided) }\end{array}$ \\
\hline $\begin{array}{c}\text { Pearson Chi-Square } \\
\text { N of Valid Cases }\end{array}$ & $\begin{array}{c}6.148(\mathrm{a}) \\
325\end{array}$ & 2 & .046 \\
\hline
\end{tabular}

(a) 0 cells $(.0 \%)$ have expected count less than 5 . The minimum expected count is 15.33 .

Table 4: Motivator Differences by Gender: “Online teaching can reduce commuting time or hassle.”

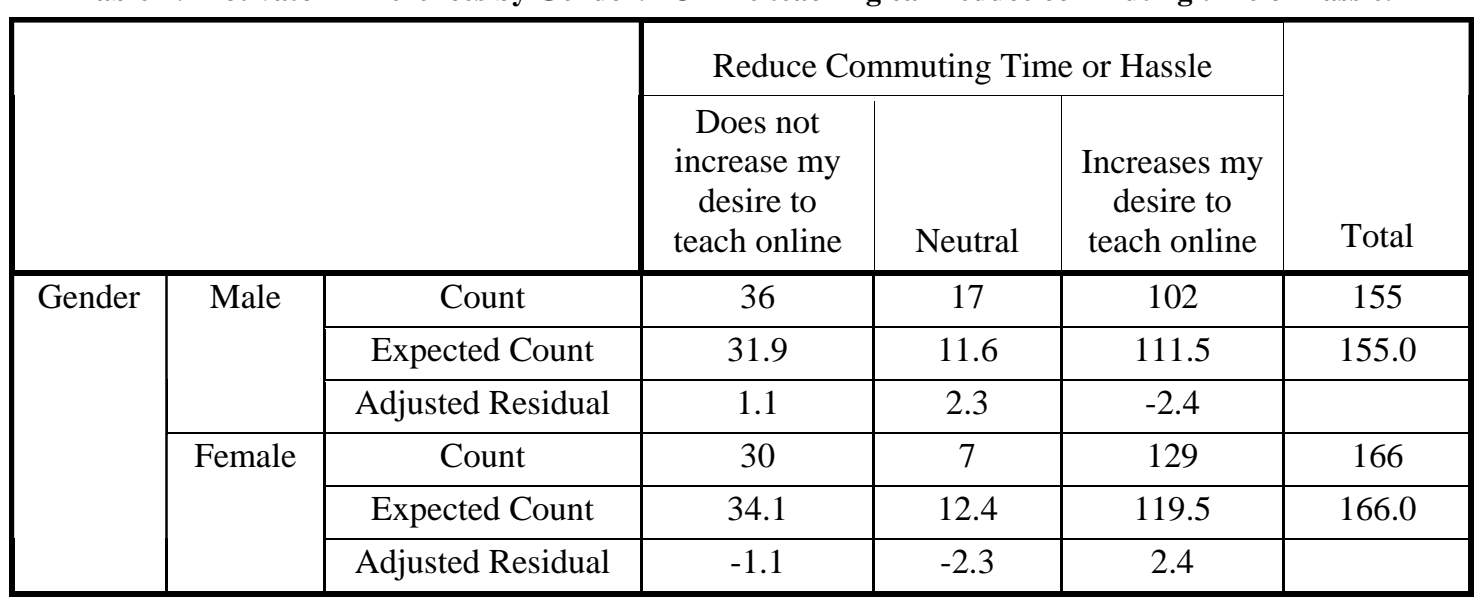

Chi-Square Tests

\begin{tabular}{|c|c|c|c|}
\hline & Value & df & $\begin{array}{c}\text { Asymp. Sig. } \\
\text { (2-sided) }\end{array}$ \\
\hline $\begin{array}{c}\text { Pearson Chi-Square } \\
\text { N of Valid Cases }\end{array}$ & $\begin{array}{c}7.500(\mathrm{a}) \\
321\end{array}$ & 2 & .024 \\
\hline
\end{tabular}

(a) 0 cells $(.0 \%)$ have expected count less than 5 . The minimum expected count is 11.59 . 
Bridges and Barriers to Teaching Online College Courses:

A Study of Experienced Online Faculty in Thirty-six Colleges

Table 5: Motivator Differences by Age: Online teaching can provide opportunities to experiment with new forms of pedagogy.

\begin{tabular}{|c|c|c|c|c|c|c|}
\hline & & & \multicolumn{3}{|c|}{ Experiment with New Pedagogy } & \multirow[b]{2}{*}{ Total } \\
\hline & & & $\begin{array}{c}\text { Does not } \\
\text { increase my } \\
\text { desire to } \\
\text { teach online }\end{array}$ & Neutral & $\begin{array}{c}\text { Increases my } \\
\text { desire to } \\
\text { teach online }\end{array}$ & \\
\hline \multirow[t]{6}{*}{ Age 2} & \multirow[t]{3}{*}{ Under 45} & Count & 3 & 15 & 81 & 99 \\
\hline & & Expected Count & 5.2 & 9.4 & 84.4 & 99.0 \\
\hline & & Adjusted Residual & -1.2 & 2.3 & $\begin{array}{ll}-1.1 \\
\end{array}$ & \\
\hline & \multirow[t]{3}{*}{45 or older } & Count & 14 & 16 & 196 & 226 \\
\hline & & Expected Count & 11.8 & 21.6 & 192.6 & 226.0 \\
\hline & & Adjusted Residual & 1.2 & -2.3 & 1.1 & \\
\hline
\end{tabular}

Chi-Square Tests

\begin{tabular}{|c|c|c|c|}
\hline & Value & df & $\begin{array}{c}\text { Asymp. Sig. } \\
\text { (2-sided) }\end{array}$ \\
\hline Pearson Chi-Square & $6.215(\mathrm{a})$ & 2 & .045 \\
N of Valid Cases & 325 & & \\
\hline
\end{tabular}

(a) 0 cells (.0\%) have expected count less than 5 . The minimum expected count is 5.18 .

Table 6: Motivator Differences by Age: Online teaching can provide opportunities to demonstrate competencies important for promotion or tenure.

\begin{tabular}{|c|c|c|c|c|c|c|}
\hline & & & \multicolumn{3}{|c|}{ Demonstrate Competencies } & \multirow[b]{2}{*}{ Total } \\
\hline & & & $\begin{array}{l}\text { Does not } \\
\text { increase my } \\
\text { desire to } \\
\text { teach online }\end{array}$ & Neutral & $\begin{array}{l}\text { Increases my } \\
\text { desire to } \\
\text { teach online }\end{array}$ & \\
\hline \multirow[t]{6}{*}{ Age 2} & \multirow[t]{3}{*}{ Under 45} & Count & 15 & 16 & 57 & 88 \\
\hline & & Expected Count & 27.0 & 15.1 & 45.9 & 88.0 \\
\hline & & Adjusted Residual & -3.4 & .3 & 2.9 & \\
\hline & \multirow[t]{3}{*}{45 or older } & Count & 71 & 32 & 89 & 192 \\
\hline & & Expected Count & 59.0 & 32.9 & 100.1 & 192.0 \\
\hline & & Adjusted Residual & 3.4 & -.3 & -2.9 & \\
\hline
\end{tabular}

Chi-Square Tests

\begin{tabular}{|c|c|c|c|}
\hline & Value & df & $\begin{array}{c}\text { Asymp. Sig. } \\
\text { (2-sided) }\end{array}$ \\
\hline Pearson Chi-Square & $11.813(\mathrm{a})$ & 2 & .003 \\
Likelihood Ratio & 12.554 & 2 & .002 \\
Linear-by-Linear & 11.300 & 1 & .001 \\
Association & 280 & & \\
N of Valid Cases & 280 & \\
\hline
\end{tabular}

(a) 0 cells (.0\%) have expected count less than 5 . The minimum expected count is 15.09 . 
Bridges and Barriers to Teaching Online College Courses: A Study of Experienced Online Faculty in Thirty-six Colleges

Table 7: Motivator Differences by Age: Additional material incentives may be available for online teaching.

\begin{tabular}{|c|c|c|c|c|c|c|}
\hline & & & \multicolumn{3}{|c|}{ Other Material Incentives } & \multirow[b]{2}{*}{ Total } \\
\hline & & & $\begin{array}{l}\text { Does not } \\
\text { increase my } \\
\text { desire to } \\
\text { teach online }\end{array}$ & Neutral & $\begin{array}{l}\text { Increases my } \\
\text { desire to } \\
\text { teach online }\end{array}$ & \\
\hline \multirow[t]{6}{*}{ Age 2} & \multirow[t]{3}{*}{ Under 45} & Count & 20 & 8 & 48 & 76 \\
\hline & & Expected Count & 28.6 & 12.5 & 35.0 & 76.0 \\
\hline & & Adjusted Residual & -2.4 & -1.7 & 3.6 & \\
\hline & \multirow[t]{3}{*}{45 or older } & Count & 74 & 33 & 67 & 174 \\
\hline & & Expected Count & 65.4 & 28.5 & 80.0 & 174.0 \\
\hline & & Adjusted Residual & 2.4 & 1.7 & -3.6 & \\
\hline
\end{tabular}

Chi-Square Tests

\begin{tabular}{|c|c|c|c|}
\hline & Value & df & $\begin{array}{c}\text { Asymp. Sig. } \\
\text { (2-sided) }\end{array}$ \\
\hline Pearson Chi-Square & $12.983(\mathrm{a})$ & 2 & .002 \\
Likelihood Ratio & 13.057 & 2 & .001 \\
Linear-by-Linear & 10.614 & 1 & .001 \\
Association & 250 & & \\
N of Valid Cases & & \\
\hline
\end{tabular}

(a) 0 cells (.0\%) have expected count less than 5 . The minimum expected count is 12.46 .

Table 8: Motivator Differences by Age: Online teaching may be a condition of your employment.

\begin{tabular}{|c|c|c|c|c|c|c|}
\hline & & & \multicolumn{3}{|c|}{ Employment } & \multirow[b]{2}{*}{ Total } \\
\hline & & & $\begin{array}{c}\text { Does not } \\
\text { increase my } \\
\text { desire to } \\
\text { teach online }\end{array}$ & Neutral & $\begin{array}{l}\text { Increases my } \\
\text { desire to } \\
\text { teach online }\end{array}$ & \\
\hline \multirow[t]{6}{*}{ Age 2} & \multirow[t]{3}{*}{ Under 45} & Count & 26 & 6 & 36 & 68 \\
\hline & & Expected Count & 33.3 & 6.8 & 27.9 & 68.0 \\
\hline & & Adjusted Residual & -2.1 & -.4 & 2.4 & \\
\hline & \multirow[t]{3}{*}{45 or older } & Count & 86 & 17 & 58 & 161 \\
\hline & & Expected Count & 78.7 & 16.2 & 66.1 & 161.0 \\
\hline & & Adjusted Residual & 2.1 & .4 & -2.4 & \\
\hline
\end{tabular}


Bridges and Barriers to Teaching Online College Courses:

A Study of Experienced Online Faculty in Thirty-six Colleges

Chi-Square Tests

\begin{tabular}{|c|c|c|c|}
\hline & Value & $\mathrm{df}$ & $\begin{array}{c}\text { Asymp. Sig. } \\
\text { (2-sided) }\end{array}$ \\
\hline Pearson Chi-Square & $5.729(\mathrm{a})$ & 2 & .057 \\
Likelihood Ratio & 5.687 & 2 & .058 \\
Linear-by-Linear & 5.489 & 1 & .019 \\
$\begin{array}{c}\text { Association } \\
\text { N of Valid Cases }\end{array}$ & 229 & & \\
\hline
\end{tabular}

(a) 0 cells $(.0 \%$ ) have expected count less than 5 . The minimum expected count is 6.83 .

Table 9: Motivator Differences by Employment Status - Full Time v. Part Time: Online teaching can accommodate other life needs.

\begin{tabular}{|c|c|c|c|c|c|c|}
\hline & & & \multicolumn{3}{|c|}{ Life Needs } & \multirow[b]{2}{*}{ Total } \\
\hline & & & $\begin{array}{c}\text { Does not } \\
\text { increase my } \\
\text { desire to } \\
\text { teach online }\end{array}$ & Neutral & $\begin{array}{c}\text { Increases my } \\
\text { desire to } \\
\text { teach online }\end{array}$ & \\
\hline \multirow{6}{*}{$\begin{array}{l}\text { Full Time - } \\
\text { Part time }\end{array}$} & \multirow{3}{*}{$\begin{array}{l}\text { Part Time - Non- } \\
\text { traditional }\end{array}$} & Count & 22 & 17 & 141 & 180 \\
\hline & & Expected Count & 29.2 & 19.3 & 131.6 & 180.0 \\
\hline & & Adjusted Residual & -2.2 & -.8 & 2.4 & \\
\hline & \multirow[t]{3}{*}{ Full Time - Traditional } & Count & 31 & 18 & 98 & 147 \\
\hline & & Expected Count & 23.8 & 15.7 & 107.4 & 147.0 \\
\hline & & Adjusted Residual & 2.2 & .8 & -2.4 & \\
\hline
\end{tabular}

\section{Chi-Square Tests}

\begin{tabular}{|c|c|c|c|}
\hline & Value & df & $\begin{array}{c}\text { Asymp. Sig. } \\
\text { (2-sided) }\end{array}$ \\
\hline Pearson Chi-Square & $6.024(\mathrm{a})$ & 2 & .049 \\
\hline Likelihood Ratio & 6.007 & 2 & .050 \\
\hline $\begin{array}{c}\text { Linear-by-Linear } \\
\text { Association }\end{array}$ & 5.973 & 1 & .015 \\
\hline N of Valid Cases & 327 & & \\
\hline
\end{tabular}

(a) 0 cells $(.0 \%)$ have expected count less than 5 . The minimum expected count is 15.73 . 
Bridges and Barriers to Teaching Online College Courses: A Study of Experienced Online Faculty in Thirty-six Colleges

Table 10: Motivator Differences by Employment Status - Full Time v. Part Time: Online Teaching can provide more free time for other professional activities.

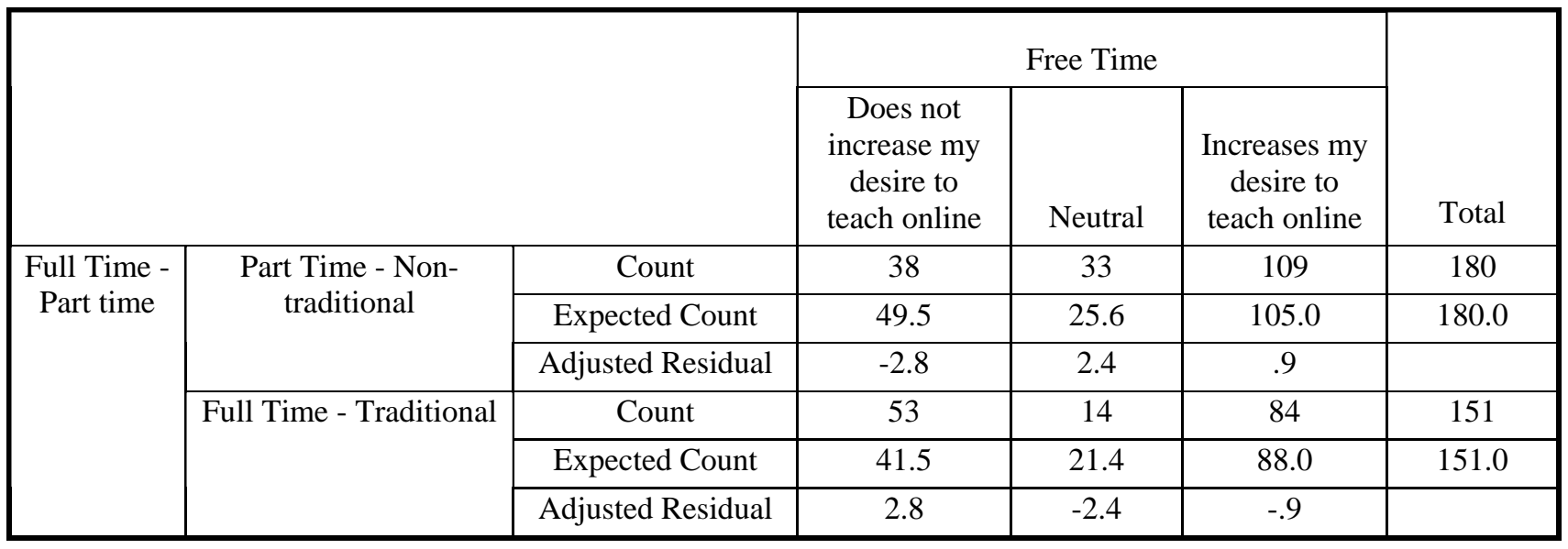

Chi-Square Tests

\begin{tabular}{|c|c|c|c|}
\hline & Value & df & $\begin{array}{c}\text { Asymp. Sig. } \\
\text { (2-sided) }\end{array}$ \\
\hline Pearson Chi-Square & $10.935(\mathrm{a})$ & 2 & .004 \\
\hline Likelihood Ratio & 11.092 & 2 & .004 \\
\hline $\begin{array}{c}\text { Linear-by-Linear } \\
\text { Association }\end{array}$ & 3.838 & 1 & .050 \\
\hline N of Valid Cases & 331 & & \\
\hline
\end{tabular}

(a) 0 cells (.0\%) have expected count less than 5 . The minimum expected count is 21.44 .

Table 11: Motivator Differences by Employment Status - Full Time v. Part Time: Online teaching can reduce commuting time or hassle.

\begin{tabular}{|c|c|c|c|c|c|c|}
\hline & & & \multicolumn{3}{|c|}{ Reduce Commuting Time or Hassle } & \multirow[b]{2}{*}{ Total } \\
\hline & & & $\begin{array}{c}\text { Does not } \\
\text { increase my } \\
\text { desire to } \\
\text { teach online }\end{array}$ & Neutral & $\begin{array}{l}\text { Increases my } \\
\text { desire to } \\
\text { teach online }\end{array}$ & \\
\hline \multirow{6}{*}{$\begin{array}{l}\text { Full Time - } \\
\text { Part time }\end{array}$} & \multirow{3}{*}{$\begin{array}{l}\text { Part Time - Non- } \\
\text { traditional }\end{array}$} & Count & 23 & 14 & 141 & 178 \\
\hline & & Expected Count & 35.8 & 13.8 & 128.4 & 178.0 \\
\hline & & Adjusted Residual & -3.6 & .1 & 3.1 & \\
\hline & \multirow[t]{3}{*}{ Full Time - Traditional } & Count & 42 & 11 & 92 & 145 \\
\hline & & Expected Count & 29.2 & 11.2 & 104.6 & 145.0 \\
\hline & & Adjusted Residual & 3.6 & -.1 & -3.1 & \\
\hline
\end{tabular}


Bridges and Barriers to Teaching Online College Courses:

A Study of Experienced Online Faculty in Thirty-six Colleges

Chi-Square Tests

\begin{tabular}{|c|c|c|c|}
\hline & Value & $\mathrm{df}$ & $\begin{array}{c}\text { Asymp. Sig. } \\
\text { (2-sided) }\end{array}$ \\
\hline Pearson Chi-Square & $12.983(\mathrm{a})$ & 2 & .002 \\
\hline Likelihood Ratio & 13.001 & 2 & .002 \\
\hline $\begin{array}{c}\text { Linear-by-Linear } \\
\text { Association }\end{array}$ & 12.361 & 1 & .000 \\
\hline N of Valid Cases & 323 & & \\
\hline
\end{tabular}

(a) 0 cells (.0\%) have expected count less than 5 . The minimum expected count is 11.22 .

Table 12: Motivator Differences by Employment Status - Full Time v. Part Time: Online teaching can provide an opportunity to teach a new subject area.

\begin{tabular}{|c|c|c|c|c|c|c|}
\hline & & & \multicolumn{3}{|c|}{ New Subject Area } & \multirow[b]{2}{*}{ Total } \\
\hline & & & $\begin{array}{c}\text { Does not } \\
\text { increase my } \\
\text { desire to } \\
\text { teach online }\end{array}$ & Neutral & $\begin{array}{c}\text { Increases my } \\
\text { desire to } \\
\text { teach online }\end{array}$ & \\
\hline \multirow{6}{*}{$\begin{array}{l}\text { Full Time - } \\
\text { Part time }\end{array}$} & \multirow{3}{*}{$\begin{array}{l}\text { Part Time - Non- } \\
\text { traditional }\end{array}$} & Count & 44 & 18 & 99 & 161 \\
\hline & & Expected Count & 52.9 & 21.6 & 86.4 & 161.0 \\
\hline & & Adjusted Residual & -2.2 & -1.2 & 2.9 & \\
\hline & \multirow[t]{3}{*}{ Full Time - Traditional } & Count & 54 & 22 & 61 & 137 \\
\hline & & Expected Count & 45.1 & 18.4 & 73.6 & 137.0 \\
\hline & & Adjusted Residual & 2.2 & 1.2 & -2.9 & \\
\hline
\end{tabular}

Chi-Square Tests

\begin{tabular}{|c|c|c|c|}
\hline & Value & df & $\begin{array}{c}\text { Asymp. Sig. } \\
\text { (2-sided) }\end{array}$ \\
\hline Pearson Chi-Square & $8.568(\mathrm{a})$ & 2 & .014 \\
\hline Likelihood Ratio & 8.600 & 2 & .014 \\
\hline $\begin{array}{c}\text { Linear-by-Linear } \\
\text { Association }\end{array}$ & 7.570 & 1 & .006 \\
\hline N of Valid Cases & 298 & & \\
\hline
\end{tabular}

(a) 0 cells (.0\%) have expected count less than 5 . The minimum expected count is 18.39 . 
Bridges and Barriers to Teaching Online College Courses: A Study of Experienced Online Faculty in Thirty-six Colleges

Table 13: Motivator Differences by Employment Status - Full Time v. Part Time: Online Teaching can promote job security.

\begin{tabular}{|c|c|c|c|c|c|c|}
\hline & & & \multicolumn{3}{|c|}{ Promote "Job Security." } & \multirow[b]{2}{*}{ Total } \\
\hline & & & $\begin{array}{c}\text { Does not } \\
\text { increase my } \\
\text { desire to } \\
\text { teach online }\end{array}$ & Neutral & $\begin{array}{c}\text { Increases my } \\
\text { desire to } \\
\text { teach online }\end{array}$ & \\
\hline \multirow{6}{*}{$\begin{array}{c}\text { Full Time - } \\
\text { Part time }\end{array}$} & \multirow{3}{*}{$\begin{array}{l}\text { Part Time - Non- } \\
\text { traditional }\end{array}$} & Count & 27 & 32 & 108 & 167 \\
\hline & & Expected Count & 35.8 & 29.0 & 102.2 & 167.0 \\
\hline & & Adjusted Residual & -2.4 & .9 & 1.3 & \\
\hline & \multirow[t]{3}{*}{ Full Time - Traditional } & Count & 41 & 23 & 86 & 150 \\
\hline & & Expected Count & 32.2 & 26.0 & 91.8 & 150.0 \\
\hline & & Adjusted Residual & 2.4 & -.9 & -1.3 & \\
\hline
\end{tabular}

Chi-Square Tests

\begin{tabular}{|c|c|c|c|}
\hline & Value & df & $\begin{array}{c}\text { Asymp. Sig. } \\
\text { (2-sided) }\end{array}$ \\
\hline Pearson Chi-Square & $5.955(\mathrm{a})$ & 2 & .051 \\
\hline Likelihood Ratio & 5.971 & 2 & .051 \\
\hline $\begin{array}{c}\text { Linear-by-Linear } \\
\text { Association }\end{array}$ & 4.034 & 1 & .045 \\
\hline N of Valid Cases & 317 & & \\
\hline
\end{tabular}

(a) 0 cells (.0\%) have expected count less than 5 . The minimum expected count is 26.03 .

Table 14: Motivator Differences by Employment Status - Full Time v. Part Time: Online teaching may be a condition of your employment.

\begin{tabular}{|c|c|c|c|c|c|c|}
\hline & & & \multicolumn{3}{|c|}{ Employment } & \multirow[b]{2}{*}{ Tota } \\
\hline & & & $\begin{array}{c}\text { Does not } \\
\text { increase my } \\
\text { desire to } \\
\text { teach online }\end{array}$ & Neutral & $\begin{array}{c}\text { Increases my } \\
\text { desire to } \\
\text { teach online }\end{array}$ & \\
\hline \multirow{6}{*}{$\begin{array}{l}\text { Full Time - } \\
\text { Part time }\end{array}$} & \multirow{3}{*}{$\begin{array}{l}\text { Part Time - Non- } \\
\text { traditional }\end{array}$} & Count & 46 & 13 & 73 & 132 \\
\hline & & Expected Count & 63.5 & 13.9 & 54.6 & 132.0 \\
\hline & & Adjusted Residual & -4.6 & -.4 & 4.9 & \\
\hline & \multirow[t]{3}{*}{ Full Time - Traditional } & Count & 68 & 12 & 25 & 105 \\
\hline & & Expected Count & 50.5 & 11.1 & 43.4 & 105.0 \\
\hline & & Adjusted Residual & 4.6 & .4 & -4.9 & \\
\hline
\end{tabular}


Bridges and Barriers to Teaching Online College Courses:

A Study of Experienced Online Faculty in Thirty-six Colleges

Chi-Square Tests

\begin{tabular}{|c|c|c|c|}
\hline & Value & df & $\begin{array}{c}\text { Asymp. Sig. } \\
\text { (2-sided) }\end{array}$ \\
\hline Pearson Chi-Square & $25.045(\mathrm{a})$ & 2 & .000 \\
\hline Likelihood Ratio & 25.784 & 2 & .000 \\
\hline $\begin{array}{c}\text { Linear-by-Linear } \\
\text { Association }\end{array}$ & 24.674 & 1 & .000 \\
\hline N of Valid Cases & 237 & & \\
\hline
\end{tabular}

(a) 0 cells (.0\%) have expected count less than 5 . The minimum expected count is 11.08 .

Table 15: Motivator Differences by Voluntariness: Online teaching can present opportunities to reflect on your classroom teaching.

\begin{tabular}{|c|c|c|c|c|c|c|}
\hline & & & \multicolumn{3}{|c|}{ Reflect on Classroom Teaching } & \multirow[t]{2}{*}{ Total } \\
\hline & & & $\begin{array}{c}\text { Does not } \\
\text { increase my } \\
\text { desire to } \\
\text { teach online }\end{array}$ & Neutral & $\begin{array}{c}\text { Increases } \\
\text { my desire } \\
\text { to teach } \\
\text { online }\end{array}$ & \\
\hline \multirow{6}{*}{$\begin{array}{l}\text { Volunteer } \\
\text { Status }\end{array}$} & \multirow[t]{3}{*}{ I was asked/required } & Count & 12 & 11 & 41 & 64 \\
\hline & & Expected Count & 7.1 & 5.8 & 51.0 & 64.0 \\
\hline & & Adjusted Residual & 2.1 & 2.5 & -3.5 & \\
\hline & \multirow[t]{3}{*}{ I volunteered } & Count & 26 & 20 & 231 & 277 \\
\hline & & Expected Count & 30.9 & 25.2 & 221.0 & 277.0 \\
\hline & & Adjusted Residual & -2.1 & -2.5 & 3.5 & \\
\hline
\end{tabular}

\section{Chi-Square Tests}

\begin{tabular}{|c|c|c|c|}
\hline & Value & df & $\begin{array}{c}\text { Asymp. Sig. } \\
\text { (2-sided) }\end{array}$ \\
\hline Pearson Chi-Square & $12.207(\mathrm{a})$ & 2 & .002 \\
\hline Likelihood Ratio & 10.933 & 2 & .004 \\
\hline $\begin{array}{c}\text { Linear-by-Linear } \\
\text { Association }\end{array}$ & 9.740 & 1 & .002 \\
\hline N of Valid Cases & 341 & & \\
\hline
\end{tabular}

(a) 0 cells (.0\%) have expected count less than 5 . The minimum expected count is 5.82 . 
Bridges and Barriers to Teaching Online College Courses: A Study of Experienced Online Faculty in Thirty-six Colleges

Table 16: Motivator Differences by Voluntariness: Online teaching can provide opportunities to experiment with new kinds of pedagogy.

\begin{tabular}{|c|c|c|c|c|c|c|}
\hline & & & \multicolumn{3}{|c|}{ Experiment with New Pedagogy } & \multirow[t]{2}{*}{ Total } \\
\hline & & & $\begin{array}{l}\text { Does not increase } \\
\text { my desire to } \\
\text { teach online }\end{array}$ & Neutral & $\begin{array}{c}\text { Increases my } \\
\text { desire to } \\
\text { teach online }\end{array}$ & \\
\hline \multirow{6}{*}{$\begin{array}{c}\text { Volunteer } \\
\text { Status }\end{array}$} & \multirow[t]{3}{*}{ I was asked/required } & Count & 8 & 13 & 48 & 69 \\
\hline & & Expected Count & 4.0 & 7.1 & 57.9 & 69.0 \\
\hline & & Adjusted Residual & 2.3 & 2.6 & -3.6 & \\
\hline & \multirow[t]{3}{*}{ I volunteered } & Count & 12 & 23 & 244 & 279 \\
\hline & & Expected Count & 16.0 & 28.9 & 234.1 & 279.0 \\
\hline & & Adjusted Residual & -2.3 & -2.6 & 3.6 & \\
\hline
\end{tabular}

Chi-Square Tests

\begin{tabular}{|c|c|c|c|}
\hline & Value & $\mathrm{df}$ & $\begin{array}{c}\text { Asymp. Sig. } \\
\text { (2-sided) }\end{array}$ \\
\hline Pearson Chi-Square & $13.235(\mathrm{a})$ & 2 & .001 \\
\hline Likelihood Ratio & 11.627 & 2 & .003 \\
\hline $\begin{array}{c}\text { Linear-by-Linear } \\
\text { Association }\end{array}$ & 12.247 & 1 & .000 \\
\hline N of Valid Cases & 348 & & \\
\hline
\end{tabular}

(a) 1 cells (16.7\%) have expected count less than 5 . The minimum expected count is 3.97 .

Table 17: Motivator Differences by Voluntariness: Online teaching can present opportunities to gain new knowledge.

\begin{tabular}{|c|c|c|c|c|c|c|}
\hline & & & \multicolumn{3}{|c|}{ Gain New Knowledge } & \multirow[b]{2}{*}{ Total } \\
\hline & & & $\begin{array}{l}\text { Does not increase } \\
\text { my desire to } \\
\text { teach online }\end{array}$ & Neutral & $\begin{array}{c}\text { Increases my } \\
\text { desire to } \\
\text { teach online }\end{array}$ & \\
\hline \multirow[t]{6}{*}{ Voluntariness 1} & \multirow[t]{3}{*}{ I was asked/required } & Count & 10 & 6 & 52 & 68 \\
\hline & & Expected Count & 4.9 & 4.7 & 58.5 & 68.0 \\
\hline & & Adjusted Residual & 2.7 & .7 & -2.5 & \\
\hline & \multirow[t]{3}{*}{ I volunteered } & Count & 15 & 18 & 249 & 282 \\
\hline & & Std. Residual & -1.1 & -.3 & .4 & \\
\hline & & Adjusted Residual & -2.7 & -.7 & 2.5 & \\
\hline
\end{tabular}

\section{Chi-Square Tests}

\begin{tabular}{|c|c|c|c|}
\hline & Value & df & $\begin{array}{c}\text { Asymp. Sig. } \\
\text { (2-sided) }\end{array}$ \\
\hline Pearson Chi-Square & $8.126(\mathrm{a})$ & 2 & .017 \\
\hline Likelihood Ratio & 6.962 & 2 & .031 \\
\hline $\begin{array}{c}\text { Linear-by-Linear } \\
\text { Association }\end{array}$ & 7.942 & 1 & .005 \\
\hline N of Valid Cases & 350 & & \\
\hline
\end{tabular}

(a) 2 cells (33.3\%) have expected count less than 5. The minimum expected count is 4.66 . 
Bridges and Barriers to Teaching Online College Courses:

A Study of Experienced Online Faculty in Thirty-six Colleges

Table 18: Motivator Differences by Voluntariness: Online teaching can help renew interest in teaching.

\begin{tabular}{|c|c|c|c|c|c|c|}
\hline \multicolumn{2}{|c|}{} & \multicolumn{3}{|c|}{ Renew Interest in Teaching } \\
\cline { 4 - 7 } & & $\begin{array}{c}\text { Does not increase } \\
\text { my desire to } \\
\text { teach online }\end{array}$ & $\begin{array}{c}\text { Increases my } \\
\text { desire to } \\
\text { teach online }\end{array}$ \\
Total \\
\hline $\begin{array}{c}\text { Voluntariness } \\
1\end{array}$
\end{tabular}

\section{Chi-Square Tests}

\begin{tabular}{|c|c|c|c|}
\hline & Value & $\mathrm{df}$ & $\begin{array}{c}\text { Asymp. Sig. } \\
\text { (2-sided) }\end{array}$ \\
\hline Pearson Chi-Square & $7.815(\mathrm{a})$ & 2 & .020 \\
\hline Likelihood Ratio & 7.052 & 2 & .029 \\
\hline $\begin{array}{c}\text { Linear-by-Linear } \\
\text { Association }\end{array}$ & 1.575 & 1 & .209 \\
\hline N of Valid Cases & 331 & & \\
\hline
\end{tabular}

(a) 0 cells (.0\%) have expected count less than 5 . The minimum expected count is 9.90 .

Table 19: Motivator Differences by Voluntariness: Online teaching may be a condition of your employment.

\begin{tabular}{|c|c|c|c|c|c|c|}
\hline & & & \multicolumn{3}{|c|}{ Employment } & \multirow[b]{2}{*}{ Total } \\
\hline & & & $\begin{array}{l}\text { Does not increase } \\
\text { my desire to } \\
\text { teach online }\end{array}$ & Neutral & $\begin{array}{l}\text { Increases my } \\
\text { desire to } \\
\text { teach online }\end{array}$ & \\
\hline \multirow{6}{*}{$\begin{array}{c}\text { Voluntariness } \\
1\end{array}$} & \multirow[t]{3}{*}{ I was asked/required } & Count & 15 & 2 & 37 & 54 \\
\hline & & Expected Count & 26.1 & 5.6 & 22.3 & 54.0 \\
\hline & & Adjusted Residual & -3.4 & -1.8 & 4.6 & \\
\hline & \multirow[t]{3}{*}{ I volunteered } & Count & 101 & 23 & 62 & 186 \\
\hline & & Expected Count & 89.9 & 19.4 & 76.7 & 186.0 \\
\hline & & Adjusted Residual & 3.4 & 1.8 & -4.6 & \\
\hline
\end{tabular}

Chi-Square Tests

\begin{tabular}{|c|c|c|c|}
\hline & Value & df & $\begin{array}{c}\text { Asymp. Sig. } \\
\text { (2-sided) }\end{array}$ \\
\hline Pearson Chi-Square & $21.666(\mathrm{a})$ & 2 & .000 \\
\hline Likelihood Ratio & 21.782 & 2 & .000 \\
\hline $\begin{array}{c}\text { Linear-by-Linear } \\
\text { Association }\end{array}$ & 17.815 & 1 & .000 \\
\hline N of Valid Cases & 240 & & \\
\hline
\end{tabular}

(a) 0 cells $(.0 \%)$ have expected count less than 5 . The minimum expected count is 5.63 . 
Bridges and Barriers to Teaching Online College Courses: A Study of Experienced Online Faculty in Thirty-six Colleges

Table 20: Motivator Differences by Voluntariness: Additional material incentives may be available for online teaching.

\begin{tabular}{|c|c|c|c|c|c|c|}
\hline & & & \multicolumn{3}{|c|}{ Other Material Incentives } & \multirow[b]{2}{*}{ Total } \\
\hline & & & $\begin{array}{l}\text { Does not increase } \\
\text { my desire to } \\
\text { teach online }\end{array}$ & Neutral & $\begin{array}{l}\text { Increases my } \\
\text { desire to } \\
\text { teach online }\end{array}$ & \\
\hline \multirow{6}{*}{$\begin{array}{c}\text { Voluntariness } \\
1\end{array}$} & \multirow[t]{3}{*}{ I was asked/required } & Count & 17 & 5 & 33 & 55 \\
\hline & & Expected Count & 20.5 & 9.1 & 25.4 & 55.0 \\
\hline & & Adjusted Residual & -1.1 & -1.7 & 2.3 & \\
\hline & \multirow[t]{3}{*}{ I volunteered } & Count & 82 & 39 & 90 & 211 \\
\hline & & Expected Count & 78.5 & 34.9 & 97.6 & 211.0 \\
\hline & & Adjusted Residual & 1.1 & 1.7 & -2.3 & \\
\hline
\end{tabular}

Chi-Square Tests

\begin{tabular}{|c|c|c|c|}
\hline & Value & df & $\begin{array}{c}\text { Asymp. Sig. } \\
\text { (2-sided) }\end{array}$ \\
\hline Pearson Chi-Square & $5.907(\mathrm{a})$ & 2 & .052 \\
\hline
\end{tabular}

(a) 0 cells $(.0 \%)$ have expected count less than 5 . The minimum expected count is 9.10 .

Table 21: Motivator Differences by Computer Skill Level: Teach in a new subject area.

\begin{tabular}{|c|c|c|c|c|c|c|}
\hline & & & \multicolumn{3}{|c|}{ New Subject Area } & \multirow[b]{2}{*}{ Total } \\
\hline & & & $\begin{array}{c}\text { Does not } \\
\text { increase my } \\
\text { desire to } \\
\text { teach online }\end{array}$ & Neutral & $\begin{array}{c}\text { Increases my } \\
\text { desire to } \\
\text { teach online }\end{array}$ & \\
\hline \multirow{9}{*}{$\begin{array}{c}\text { Computer } \\
\text { Skill }\end{array}$} & \multirow[t]{3}{*}{ Low } & Count & 11 & 2 & 10 & 23 \\
\hline & & Expected Count & 7.7 & 3.1 & 12.2 & 23.0 \\
\hline & & Adjusted Residual & 1.5 & -.7 & -1.0 & \\
\hline & \multirow[t]{3}{*}{ Medium } & Count & 46 & 27 & 67 & 140 \\
\hline & & Expected Count & 47.1 & 18.7 & 74.2 & 140.0 \\
\hline & & Adjusted Residual & -.3 & 2.8 & -1.7 & \\
\hline & \multirow[t]{3}{*}{ High } & Count & 44 & 11 & 82 & 137 \\
\hline & & Expected Count & 46.1 & 18.3 & 72.6 & 137.0 \\
\hline & & Adjusted Residual & -.5 & -2.5 & 2.2 & \\
\hline
\end{tabular}

Chi-Square Tests

\begin{tabular}{|c|c|c|c|}
\hline & Value & df & $\begin{array}{c}\text { Asymp. Sig. } \\
\text { (2-sided) }\end{array}$ \\
\hline Pearson Chi-Square & $10.783(\mathrm{a})$ & 4 & .029 \\
\hline Likelihood Ratio & 10.707 & 4 & .030 \\
\hline $\begin{array}{c}\text { Linear-by-Linear } \\
\text { Association }\end{array}$ & 2.963 & 1 & .085 \\
\hline N of Valid Cases & 300 & & \\
\hline
\end{tabular}

(a) 1 cells $(11.1 \%)$ have expected count less than 5 . The minimum expected count is 3.07 . 
Bridges and Barriers to Teaching Online College Courses:

A Study of Experienced Online Faculty in Thirty-six Colleges

Table 22: Motivator Differences by Computer Skill Level: Online teaching can represent a new challenge.

\begin{tabular}{|c|c|c|c|c|c|c|}
\hline & & & \multicolumn{3}{|c|}{ New Challenge } & \multirow[b]{2}{*}{ Total } \\
\hline & & & $\begin{array}{c}\text { Does not } \\
\text { increase my } \\
\text { desire to } \\
\text { teach online }\end{array}$ & Neutral & $\begin{array}{l}\text { Increases my } \\
\text { desire to } \\
\text { teach online }\end{array}$ & \\
\hline \multirow{9}{*}{$\begin{array}{c}\text { Computer } \\
\text { Skill }\end{array}$} & \multirow[t]{3}{*}{ Low } & Count & 0 & 4 & 23 & 27 \\
\hline & & Expected Count & 1.6 & 2.0 & 23.4 & 27.0 \\
\hline & & Adjusted Residual & -1.4 & 1.5 & -.2 & \\
\hline & \multirow[t]{3}{*}{ Medium } & Count & 4 & 18 & 142 & 164 \\
\hline & & Expected Count & 9.8 & 12.2 & 142.0 & 164.0 \\
\hline & & Adjusted Residual & -2.6 & 2.4 & .0 & \\
\hline & \multirow[t]{3}{*}{ High } & Count & 17 & 4 & 138 & 159 \\
\hline & & Expected Count & 9.5 & 11.8 & 137.6 & 159.0 \\
\hline & & Adjusted Residual & 3.4 & -3.2 & .1 & \\
\hline
\end{tabular}

Chi-Square Tests

\begin{tabular}{|c|c|c|c|}
\hline & Value & df & $\begin{array}{c}\text { Asymp. Sig. } \\
\text { (2-sided) }\end{array}$ \\
\hline Pearson Chi-Square & $20.853(\mathrm{a})$ & 4 & .000 \\
\hline Likelihood Ratio & 23.361 & 4 & .000 \\
\hline $\begin{array}{c}\text { Linear-by-Linear } \\
\text { Association }\end{array}$ & 1.848 & 1 & .174 \\
\hline N of Valid Cases & 350 & & \\
\hline
\end{tabular}

(a) 2 cells (22.2\%) have expected count less than 5 . The minimum expected count is 1.62.

Table 23: Motivator Differences by Computer Skill Level: Online teaching can be an opportunity to act as a mentor.

\begin{tabular}{|c|c|c|c|c|c|c|}
\hline & & & \multicolumn{3}{|c|}{ Mentor } & \multirow[b]{2}{*}{ Total } \\
\hline & & & $\begin{array}{c}\text { Does not } \\
\text { increase my } \\
\text { desire to } \\
\text { teach online }\end{array}$ & Neutral & $\begin{array}{l}\text { Increases my } \\
\text { desire to } \\
\text { teach online }\end{array}$ & \\
\hline \multirow{8}{*}{$\begin{array}{l}\text { Computer } \\
\text { Skill }\end{array}$} & \multirow[t]{2}{*}{ Low } & Count & 9 & 4 & 13 & 26 \\
\hline & & Expected Count & 6.8 & 4.2 & 15.0 & 26.0 \\
\hline & \multirow[t]{3}{*}{ Medium } & Count & 41 & 33 & 79 & 153 \\
\hline & & Expected Count & 39.8 & 25.0 & 88.3 & 153.0 \\
\hline & & Adjusted Residual & .3 & 2.4 & -2.1 & \\
\hline & \multirow[t]{3}{*}{ High } & Count & 36 & 17 & 99 & 152 \\
\hline & & Expected Count & 39.5 & 24.8 & 87.7 & 152.0 \\
\hline & & Adjusted Residual & -.9 & -2.3 & 2.5 & \\
\hline
\end{tabular}


Bridges and Barriers to Teaching Online College Courses:

A Study of Experienced Online Faculty in Thirty-six Colleges

Chi-Square Tests

\begin{tabular}{|c|c|c|c|}
\hline & Value & df & $\begin{array}{c}\text { Asymp. Sig. } \\
\text { (2-sided) }\end{array}$ \\
\hline Pearson Chi-Square & $8.846(\mathrm{a})$ & 4 & .065 \\
\hline Likelihood Ratio & 8.842 & 4 & .065 \\
\hline $\begin{array}{c}\text { Linear-by-Linear } \\
\text { Association }\end{array}$ & 3.771 & 1 & .052 \\
\hline N of Valid Cases & 331 & & \\
\hline
\end{tabular}

(a) 1 cells (11.1\%) have expected count less than 5. The minimum expected count is 4.24 .

Table 24: Institutional Differences: Voluntariness by institution type.

\begin{tabular}{|c|c|c|c|c|c|c|}
\hline & & & \multicolumn{3}{|c|}{ Voluntary Online Teaching } & \multirow[b]{2}{*}{ Total } \\
\hline & & & $\begin{array}{c}\text { I was } \\
\text { asked/required }\end{array}$ & Neutral & I volunteered & \\
\hline \multirow{6}{*}{$\begin{array}{l}\text { 2-year or } \\
\text { 4-year }\end{array}$} & \multirow[t]{3}{*}{ Two-year colleges } & Count & 14 & 5 & 185 & 204 \\
\hline & & Expected Count & 33.2 & 5.1 & 165.8 & 204.0 \\
\hline & & Adjusted Residual & -5.5 & .0 & 5.2 & \\
\hline & \multirow[t]{3}{*}{ Four-year + colleges } & Count & 45 & 4 & 110 & 159 \\
\hline & & Expected Count & 25.8 & 3.9 & 129.2 & 159.0 \\
\hline & & Adjusted Residual & 5.5 & .0 & -5.2 & \\
\hline
\end{tabular}

\section{Chi-Square Tests}

\begin{tabular}{|c|c|c|c|}
\hline & Value & $\mathrm{df}$ & $\begin{array}{c}\text { Asymp. Sig. } \\
\text { (2-sided) }\end{array}$ \\
\hline Pearson Chi-Square & $30.355(\mathrm{a})$ & 2 & .000 \\
\hline Likelihood Ratio & 30.932 & 2 & .000 \\
\hline $\begin{array}{c}\text { Linear-by-Linear } \\
\text { Association }\end{array}$ & 29.741 & 1 & .000 \\
\hline N of Valid Cases & 363 & & \\
\hline
\end{tabular}

(a) 1 cells (16.7\%) have expected count less than 5. The minimum expected count is 3.94. 
Bridges and Barriers to Teaching Online College Courses:

A Study of Experienced Online Faculty in Thirty-six Colleges

Table 25: Institutional Differences: Two-year v. Four-year Colleges: Online teaching can accommodate other life needs.

\begin{tabular}{|c|c|c|c|c|c|c|}
\hline & & & \multicolumn{3}{|c|}{ Life Needs } & \multirow[b]{2}{*}{ Total } \\
\hline & & & $\begin{array}{l}\text { Does not increase } \\
\text { my desire to } \\
\text { teach online }\end{array}$ & Neutral & $\begin{array}{l}\text { Increases my } \\
\text { desire to } \\
\text { teach online }\end{array}$ & \\
\hline \multirow{6}{*}{$\begin{array}{c}\text { 2-year or } \\
4 \text {-year }\end{array}$} & \multirow[t]{3}{*}{ Two-year colleges } & Count & 33 & 27 & 125 & 185 \\
\hline & & Expected Count & 31.5 & 19.7 & 133.8 & 185.0 \\
\hline & & Adjusted Residual & .4 & 2.6 & -2.2 & \\
\hline & \multirow[t]{3}{*}{ Four-year + colleges } & Count & 23 & 8 & 113 & 144 \\
\hline & & Expected Count & 24.5 & 15.3 & 104.2 & 144.0 \\
\hline & & Adjusted Residual & -.4 & -2.6 & 2.2 & \\
\hline
\end{tabular}

Chi-Square Tests

\begin{tabular}{|c|c|c|c|}
\hline & Value & df & $\begin{array}{c}\text { Asymp. Sig. } \\
\text { (2-sided) }\end{array}$ \\
\hline Pearson Chi-Square & $7.715(\mathrm{a})$ & 2 & .021 \\
\hline Likelihood Ratio & 8.170 & 2 & .017 \\
\hline $\begin{array}{c}\text { Linear-by-Linear } \\
\text { Association }\end{array}$ & 2.240 & 1 & .134 \\
\hline N of Valid Cases & 329 & & \\
\hline
\end{tabular}

(a) 0 cells $(.0 \%)$ have expected count less than 5 . The minimum expected count is 15.32 .

Table 26: Institutional Differences: Two-year v. Four-year Colleges: Online teaching can provide an opportunity to teach in a new subject area.

\begin{tabular}{|c|c|c|c|c|c|c|}
\hline & & & \multicolumn{3}{|c|}{ New Subject Area } & \multirow[b]{2}{*}{ Total } \\
\hline & & & $\begin{array}{l}\text { Does not increase } \\
\text { my desire to } \\
\text { teach online }\end{array}$ & Neutral & $\begin{array}{c}\text { Increases my } \\
\text { desire to } \\
\text { teach online }\end{array}$ & \\
\hline \multirow{6}{*}{$\begin{array}{c}\text { 2-year or } \\
\text { 4-year }\end{array}$} & \multirow[t]{3}{*}{ Two-year colleges } & Count & 64 & 26 & 75 & 165 \\
\hline & & Expected Count & 55.6 & 22.0 & 87.5 & 165.0 \\
\hline & & Adjusted Residual & 2.1 & 1.4 & -2.9 & \\
\hline & \multirow[t]{3}{*}{ Four-year + colleges } & Count & 37 & 14 & 84 & 135 \\
\hline & & Expected Count & 45.5 & 18.0 & 71.6 & 135.0 \\
\hline & & Adjusted Residual & -2.1 & -1.4 & 2.9 & \\
\hline
\end{tabular}

Chi-Square Tests

\begin{tabular}{|c|c|c|c|}
\hline & Value & df & $\begin{array}{c}\text { Asymp. Sig. } \\
\text { (2-sided) }\end{array}$ \\
\hline Pearson Chi-Square & $8.411(\mathrm{a})$ & 2 & .015 \\
\hline Likelihood Ratio & 8.467 & 2 & .015 \\
\hline $\begin{array}{c}\text { Linear-by-Linear } \\
\text { Association }\end{array}$ & 7.070 & 1 & .008 \\
\hline N of Valid Cases & 300 & & \\
\hline
\end{tabular}

(a) 0 cells (.0\%) have expected count less than 5 . The minimum expected count is 18.00 . 
Bridges and Barriers to Teaching Online College Courses: A Study of Experienced Online Faculty in Thirty-six Colleges

Table 27: Institutional Differences: Two Year v. Four-year Colleges: Online Teaching can provide an opportunity to reflect on classroom teaching.

\begin{tabular}{|c|c|c|c|c|c|c|}
\hline & & & \multicolumn{3}{|c|}{ Reflect and Think Classroom Teaching } & \multirow[b]{2}{*}{ Total } \\
\hline & & & $\begin{array}{l}\text { Does not increase } \\
\text { my desire to } \\
\text { teach online }\end{array}$ & Neutral & $\begin{array}{c}\text { Increases my } \\
\text { desire to } \\
\text { teach online }\end{array}$ & \\
\hline \multirow{6}{*}{$\begin{array}{l}\text { 2-year or } \\
\text { 4-year }\end{array}$} & \multirow[t]{3}{*}{ Two-year colleges } & Count & 15 & 16 & 161 & 192 \\
\hline & & Expected Count & 21.5 & 17.5 & 153.0 & 192.0 \\
\hline & & Adjusted Residual & -2.2 & -.6 & 2.2 & \\
\hline & \multirow[t]{3}{*}{ Four-year + colleges } & Count & 23 & 15 & 110 & 148 \\
\hline & & Expected Count & 16.5 & 13.5 & 118.0 & 148.0 \\
\hline & & Adjusted Residual & 2.2 & .6 & -2.2 & \\
\hline
\end{tabular}

Chi-Square Tests

\begin{tabular}{|c|c|c|c|}
\hline & Value & df & $\begin{array}{c}\text { Asymp. Sig. } \\
\text { (2-sided) }\end{array}$ \\
\hline Pearson Chi-Square & $5.716(\mathrm{a})$ & 2 & .057 \\
\hline Likelihood Ratio & 5.674 & 2 & .059 \\
\hline $\begin{array}{c}\text { Linear-by-Linear } \\
\text { Association }\end{array}$ & 5.651 & 1 & .017 \\
\hline N of Valid Cases & 340 & & \\
\hline
\end{tabular}

(a) 0 cells $(.0 \%)$ have expected count less than 5 . The minimum expected count is 13.49 .

Table 28: Institutional Differences: Two-year v. Four-year Colleges: Online teaching can promote job security.

\begin{tabular}{|c|c|c|c|c|c|c|}
\hline & & & \multicolumn{3}{|c|}{ Promote "Job Security." } & \multirow[b]{2}{*}{ Total } \\
\hline & & & $\begin{array}{c}\text { Does not increase } \\
\text { my desire to } \\
\text { teach online }\end{array}$ & Neutral & $\begin{array}{l}\text { Increases my } \\
\text { desire to } \\
\text { teach online }\end{array}$ & \\
\hline \multirow{6}{*}{$\begin{array}{c}\text { 2-year or } \\
4 \text {-year }\end{array}$} & \multirow[t]{3}{*}{ Two-year colleges } & Count & 31 & 31 & 121 & 183 \\
\hline & & Expected Count & 40.2 & 31.6 & 111.3 & 183.0 \\
\hline & & Adjusted Residual & -2.5 & -.2 & 2.3 & \\
\hline & \multirow[t]{3}{*}{ Four-year + colleges } & Count & 39 & 24 & 73 & 136 \\
\hline & & Expected Count & 29.8 & 23.4 & 82.7 & 136.0 \\
\hline & & Adjusted Residual & 2.5 & .2 & -2.3 & \\
\hline
\end{tabular}


Bridges and Barriers to Teaching Online College Courses:

A Study of Experienced Online Faculty in Thirty-six Colleges

Chi-Square Tests

\begin{tabular}{|c|c|c|c|}
\hline & Value & $\mathrm{df}$ & $\begin{array}{c}\text { Asymp. Sig. } \\
\text { (2-sided) }\end{array}$ \\
\hline Pearson Chi-Square & $6.907(\mathrm{a})$ & 2 & .032 \\
\hline Likelihood Ratio & 6.860 & 2 & .032 \\
\hline $\begin{array}{c}\text { Linear-by-Linear } \\
\text { Association }\end{array}$ & 6.722 & 1 & .010 \\
\hline N of Valid Cases & 319 & & \\
\hline
\end{tabular}

(a) 0 cells $(.0 \%)$ have expected count less than 5 . The minimum expected count is 23.45 .

Table 29: Institutional Differences: Two-year v. Four-year Colleges: Online teaching may be a condition of your employment.

\begin{tabular}{|c|c|c|c|c|c|c|}
\hline & \multicolumn{3}{|c|}{ Employment } & \multirow[b]{2}{*}{ Total } \\
\hline & & & $\begin{array}{l}\text { Does not increase } \\
\text { my desire to } \\
\text { teach online }\end{array}$ & Neutral & $\begin{array}{c}\text { Increases my } \\
\text { desire to } \\
\text { teach online }\end{array}$ & \\
\hline \multirow{6}{*}{$\begin{array}{c}\text { 2-year or } \\
\text { 4-year }\end{array}$} & \multirow[t]{3}{*}{ Two-year colleges } & Count & 73 & 13 & 41 & 127 \\
\hline & & Expected Count & 61.6 & 13.3 & 52.1 & 127.0 \\
\hline & & Adjusted Residual & 2.9 & -.1 & -2.9 & \\
\hline & \multirow[t]{3}{*}{ Four-year + colleges } & Count & 43 & 12 & 57 & 112 \\
\hline & & Expected Count & 54.4 & 11.7 & 45.9 & 112.0 \\
\hline & & Adjusted Residual & -2.9 & .1 & 2.9 & \\
\hline
\end{tabular}

Chi-Square Tests

\begin{tabular}{|c|c|c|c|}
\hline & Value & df & $\begin{array}{c}\text { Asymp. Sig. } \\
\text { (2-sided) }\end{array}$ \\
\hline Pearson Chi-Square & $9.507(\mathrm{a})$ & 2 & .009 \\
\hline Likelihood Ratio & 9.569 & 2 & .008 \\
\hline $\begin{array}{c}\text { Linear-by-Linear } \\
\text { Association }\end{array}$ & 9.466 & 1 & .002 \\
\hline N of Valid Cases & 239 & & \\
\hline
\end{tabular}

(a) 0 cells (.0\%) have expected count less than 5 . The minimum expected count is 11.72 


\section{Disadvantages/Demotivators}

Table 30: Descriptive Statistics for Demotivators for Teaching Online

\begin{tabular}{|c|c|c|c|}
\hline & $\mathrm{N}$ & Mean & SD \\
\hline \multicolumn{4}{|l|}{ There may be inadequate compensation... } \\
\hline 54. ...for online course development. & 296 & 4.15 & 2.29 \\
\hline 56. ... for online course revision. & 307 & 4.14 & 2.26 \\
\hline 55. ... for online teaching. & 300 & 4.07 & 2.31 \\
\hline $\begin{array}{l}\text { 46. Students may lack adequate access to participate effectively in online } \\
\text { courses. }\end{array}$ & 314 & 3.84 & 2.00 \\
\hline $\begin{array}{l}\text { 60. The campus administration may not recognize the effort required to teach } \\
\text { online. }\end{array}$ & 289 & 3.82 & 2.30 \\
\hline 52. Online teaching may take more time than classroom teaching. & 319 & 3.71 & 2.24 \\
\hline 50. Inadequate time to develop a new online. & 288 & 3.64 & 2.13 \\
\hline $\begin{array}{l}\text { 39. A lack of recognition of online teaching in regards to considerations for } \\
\text { promotion and/or salary increase. }\end{array}$ & 260 & 3.61 & 2.13 \\
\hline 51. Inadequate time to revise online courses. & 297 & 3.59 & 2.10 \\
\hline $\begin{array}{l}\text { 42. The absence of face-to-face interaction with students can be a } \\
\text { disadvantage. }\end{array}$ & 319 & 3.53 & 2.09 \\
\hline 45. Inadequate technical support for online course teaching. & 284 & 3.42 & 2.21 \\
\hline 44. Inadequate technical support for online course development. & 276 & 3.37 & 2.24 \\
\hline $\begin{array}{l}\text { 38. A lack of recognition of online teaching in regards to tenure } \\
\text { considerations. }\end{array}$ & 239 & 3.35 & 2.09 \\
\hline $\begin{array}{l}\text { 48. There may be little or no opportunity to experiment with the technology } \\
\text { for teaching online prior to committing to teach online. }\end{array}$ & 307 & 3.33 & 2.01 \\
\hline 40. Developing an online course can be complicated. & 319 & 3.27 & 2.01 \\
\hline 49. Inadequate time to learn about online teaching. & 291 & 3.24 & 1.99 \\
\hline 53. Concerns about intellectual property and teaching online. & 310 & 3.20 & 2.08 \\
\hline $\begin{array}{l}\text { 47. There may be little or no opportunity to observe other faculty using } \\
\text { technology for online teaching prior to committing to teach online. }\end{array}$ & 303 & 3.17 & 1.91 \\
\hline 59. The campus administration may not value online teaching. & 281 & 3.06 & 2.06 \\
\hline $\begin{array}{l}\text { 57. Concerns that online course offerings may reduce the quality of our } \\
\text { institution's reputation. }\end{array}$ & 302 & 2.87 & 1.94 \\
\hline 43. Effective pedagogy for online teaching may be unfamiliar. & 314 & 2.86 & 1.71 \\
\hline 41. The technology involved in online teaching can be confusing. & 321 & 2.85 & 1.83 \\
\hline 58. Colleagues may talk negatively about online teaching. & 300 & 2.58 & 1.87 \\
\hline
\end{tabular}

Note: Range $=1$ (not a demotivator) to 7 (strongest demotivator) 
Bridges and Barriers to Teaching Online College Courses:

A Study of Experienced Online Faculty in Thirty-six Colleges

Table 31: Age Differences - A Lack of Recognition of Online Teaching in Regards to Tenure Considerations

\begin{tabular}{|c|c|c|c|c|c|c|}
\hline & & & \multicolumn{3}{|c|}{ Lack of Recognition (Tenure) } & \multirow[b]{2}{*}{ Total } \\
\hline & & & $\begin{array}{l}\text { Does not decrease } \\
\text { my desire to teach } \\
\text { online }\end{array}$ & Neutral & $\begin{array}{l}\text { Decreases } \\
\text { my desire to } \\
\text { teach online }\end{array}$ & \\
\hline \multirow[t]{6}{*}{ Age 2} & \multirow[t]{3}{*}{ Under 45} & Count & 29 & 19 & 27 & 75 \\
\hline & & Expected Count & 37.0 & 18.2 & 19.8 & 75.0 \\
\hline & & Adjusted Residual & -2.3 & .3 & 2.3 & \\
\hline & \multirow[t]{3}{*}{45 or older } & Count & 83 & 36 & 33 & 152 \\
\hline & & Expected Count & 75.0 & 36.8 & 40.2 & 152.0 \\
\hline & & Adjusted Residual & 2.3 & -.3 & -2.3 & \\
\hline \multirow{2}{*}{\multicolumn{2}{|c|}{ Total }} & Count & 112 & 55 & 60 & 227 \\
\hline & & Expected Count & 112.0 & 55.0 & 60.0 & 227.0 \\
\hline
\end{tabular}

Chi-Square Tests

\begin{tabular}{|c|c|c|c|}
\hline & Value & $\mathrm{df}$ & $\begin{array}{c}\text { Asymp. Sig. } \\
\text { (2-sided) }\end{array}$ \\
\hline Pearson Chi-Square & $6.522(\mathrm{a})$ & 2 & .038 \\
Likelihood Ratio & 6.450 & 2 & .040 \\
$\begin{array}{c}\text { Linear-by-Linear } \\
\text { Association }\end{array}$ & 6.478 & 1 & .011 \\
$\mathrm{~N}$ of Valid Cases & 227 & & \\
\hline
\end{tabular}

(a) 0 cells (.0\%) have expected count less than 5 . The minimum expected count is 18.17 .

Table 32: Age Differences: A Lack of Recognition of Online Teaching in Regards to Considerations for Promotion and/or Salary Increase

\begin{tabular}{|c|c|c|c|c|c|c|}
\hline & & & \multicolumn{3}{|c|}{ Lack of Recognition (Promotion and Salary) } & \multirow[b]{2}{*}{ Total } \\
\hline & & & $\begin{array}{l}\text { Does not decrease } \\
\text { my desire to teach } \\
\text { online }\end{array}$ & Neutral & $\begin{array}{c}\text { Decreases my } \\
\text { desire to teach } \\
\text { online }\end{array}$ & \\
\hline \multirow[t]{6}{*}{ Age 2} & \multirow[t]{3}{*}{ Under 45} & Count & 27 & 19 & 32 & 78 \\
\hline & & Expected Count & 34.6 & 18.7 & 24.7 & 78.0 \\
\hline & & Adjusted Residual & -2.1 & .1 & 2.1 & \\
\hline & \multirow[t]{3}{*}{45 or older } & Count & 82 & 40 & 46 & 168 \\
\hline & & Expected Count & 74.4 & 40.3 & 53.3 & 168.0 \\
\hline & & Adjusted Residual & 2.1 & -.1 & -2.1 & \\
\hline \multirow{2}{*}{\multicolumn{2}{|c|}{ Total }} & Count & 109 & 59 & 78 & 246 \\
\hline & & Expected Count & 109.0 & 59.0 & 78.0 & 246.0 \\
\hline
\end{tabular}


Bridges and Barriers to Teaching Online College Courses:

A Study of Experienced Online Faculty in Thirty-six Colleges

Chi-Square Tests

\begin{tabular}{|c|c|c|c|}
\hline & Value & df & $\begin{array}{c}\text { Asymp. Sig. } \\
\text { (2-sided) }\end{array}$ \\
\hline Pearson Chi-Square & $5.557(\mathrm{a})$ & 2 & .062 \\
\hline Likelihood Ratio & 5.533 & 2 & .063 \\
\hline $\begin{array}{c}\text { Linear-by-Linear } \\
\text { Association }\end{array}$ & 5.524 & 1 & .019 \\
\hline N of Valid Cases & 246 & & \\
\hline
\end{tabular}

(a) 0 cells $(.0 \%)$ have expected count less than 5 . The minimum expected count is 18.71 .

Table 33: Age Differences: Online Teaching May Not Be Valued By Campus Administration.

\begin{tabular}{|c|c|c|c|c|c|c|}
\hline & & & \multicolumn{3}{|c|}{ Not Valued by Campus Administration } & \multirow[b]{2}{*}{ Total } \\
\hline & & & $\begin{array}{l}\text { Does not decrease } \\
\text { my desire to teach } \\
\text { online }\end{array}$ & Neutral & $\begin{array}{c}\text { Decreases } \\
\text { my desire to } \\
\text { teach online }\end{array}$ & \\
\hline \multirow[t]{6}{*}{ Age 2} & \multirow[t]{3}{*}{ Under 45} & Count & 40 & 16 & 27 & 83 \\
\hline & & Expected Count & 50.2 & 11.9 & 20.9 & 83.0 \\
\hline & & Adjusted Residual & -2.8 & 1.6 & 1.9 & \\
\hline & \multirow[t]{3}{*}{45 or older } & Count & 121 & 22 & 40 & 183 \\
\hline & & Expected Count & 110.8 & 26.1 & 46.1 & 183.0 \\
\hline & & Adjusted Residual & 2.8 & -1.6 & -1.9 & \\
\hline \multirow{2}{*}{\multicolumn{2}{|c|}{ Total }} & Count & 161 & 38 & 67 & 266 \\
\hline & & Expected Count & 161.0 & 38.0 & 67.0 & 266.0 \\
\hline
\end{tabular}

Chi-Square Tests

\begin{tabular}{|c|c|c|c|}
\hline & Value & df & $\begin{array}{c}\text { Asymp. Sig. } \\
\text { (2-sided) }\end{array}$ \\
\hline Pearson Chi-Square & $7.718(\mathrm{a})$ & 2 & .021 \\
\hline Likelihood Ratio & 7.629 & 2 & .022 \\
\hline $\begin{array}{c}\text { Linear-by-Linear } \\
\text { Association }\end{array}$ & 6.354 & 1 & .012 \\
\hline N of Valid Cases & 266 & & \\
\hline
\end{tabular}

(a) 0 cells (.0\%) have expected count less than 5 . The minimum expected count is 11.86 . 
Bridges and Barriers to Teaching Online College Courses:

A Study of Experienced Online Faculty in Thirty-six Colleges

Table 34: Age Differences: Some people say that online courses are of an inferior quality compared to classroom-based courses.

\begin{tabular}{|c|c|c|c|c|c|c|}
\hline & \multicolumn{3}{|c|}{ Inferior Quality } & \multirow[b]{2}{*}{ Total } \\
\hline & & & $\begin{array}{l}\text { Does not decrease } \\
\text { my desire to teach } \\
\text { online }\end{array}$ & Neutral & $\begin{array}{l}\text { Decreases } \\
\text { my desire to } \\
\text { teach online }\end{array}$ & \\
\hline \multirow[t]{6}{*}{ Age 2} & \multirow[t]{3}{*}{ Under 45} & Count & 49 & 10 & 27 & 86 \\
\hline & & Expected Count & 55.2 & 11.0 & 19.9 & 86.0 \\
\hline & & Adjusted Residual & -1.7 & -.4 & 2.2 & \\
\hline & \multirow[t]{3}{*}{45 or older } & Count & 137 & 27 & 40 & 204 \\
\hline & & Expected Count & 130.8 & 26.0 & 47.1 & 204.0 \\
\hline & & Adjusted Residual & 1.7 & .4 & -2.2 & \\
\hline \multirow{2}{*}{\multicolumn{2}{|c|}{ Total }} & Count & 186 & 37 & 67 & 290 \\
\hline & & Expected Count & 186.0 & 37.0 & 67.0 & 290.0 \\
\hline
\end{tabular}

Chi-Square Tests

\begin{tabular}{|c|c|c|c|}
\hline & Value & df & $\begin{array}{c}\text { Asymp. Sig. } \\
\text { (2-sided) }\end{array}$ \\
\hline Pearson Chi-Square & $4.738(\mathrm{a})$ & 2 & .094 \\
\hline Likelihood Ratio & 4.561 & 2 & .102 \\
\hline $\begin{array}{c}\text { Linear-by-Linear } \\
\text { Association }\end{array}$ & 4.132 & 1 & .042 \\
\hline N of Valid Cases & 290 & & \\
\hline
\end{tabular}

(a) 0 cells $(.0 \%)$ have expected count less than 5 . The minimum expected count is 10.97 .

Table 35: Tenured v. Untenured Faculty: There may be inadequate compensation for online course development.

\begin{tabular}{|c|c|c|c|c|c|c|}
\hline & & & \multicolumn{3}{|c|}{$\begin{array}{l}\text { Inadequate Compensation (Course } \\
\text { Development) }\end{array}$} & \multirow[b]{2}{*}{ Total } \\
\hline & & & $\begin{array}{c}\text { Does not } \\
\text { decrease my } \\
\text { desire to teach } \\
\text { online }\end{array}$ & Neutral & $\begin{array}{l}\text { Decreases my } \\
\text { desire to } \\
\text { teach online }\end{array}$ & \\
\hline \multirow[t]{6}{*}{ Tenure } & \multirow[t]{3}{*}{ Untenured } & Count & 75 & 23 & 102 & 200 \\
\hline & & Expected Count & 82.6 & 23.9 & 93.5 & 200.0 \\
\hline & & Adjusted Residual & -1.9 & -.3 & 2.1 & \\
\hline & \multirow[t]{3}{*}{ Tenured } & Count & 46 & 12 & 35 & 93 \\
\hline & & Expected Count & 38.4 & 11.1 & 43.5 & 93.0 \\
\hline & & Adjusted Residual & 1.9 & .3 & -2.1 & \\
\hline \multirow{2}{*}{\multicolumn{2}{|c|}{ Total }} & Count & 121 & 35 & 137 & 293 \\
\hline & & Expected Count & 121.0 & 35.0 & 137.0 & 293.0 \\
\hline
\end{tabular}


Bridges and Barriers to Teaching Online College Courses:

A Study of Experienced Online Faculty in Thirty-six Colleges

Chi-Square Tests

\begin{tabular}{|c|c|c|c|}
\hline & Value & df & $\begin{array}{c}\text { Asymp. Sig. } \\
\text { (2-sided) }\end{array}$ \\
\hline Pearson Chi-Square & $4.730(\mathrm{a})$ & 2 & .094 \\
\hline Likelihood Ratio & 4.758 & 2 & .093 \\
\hline $\begin{array}{c}\text { Linear-by-Linear } \\
\text { Association }\end{array}$ & 4.625 & 1 & .032 \\
\hline N of Valid Cases & 293 & & \\
\hline
\end{tabular}

(a) 0 cells $(.0 \%)$ have expected count less than 5 . The minimum expected count is 11.11 .

Table 36: Tenured v. Untenured Faculty: There may be inadequate compensation for online teaching.

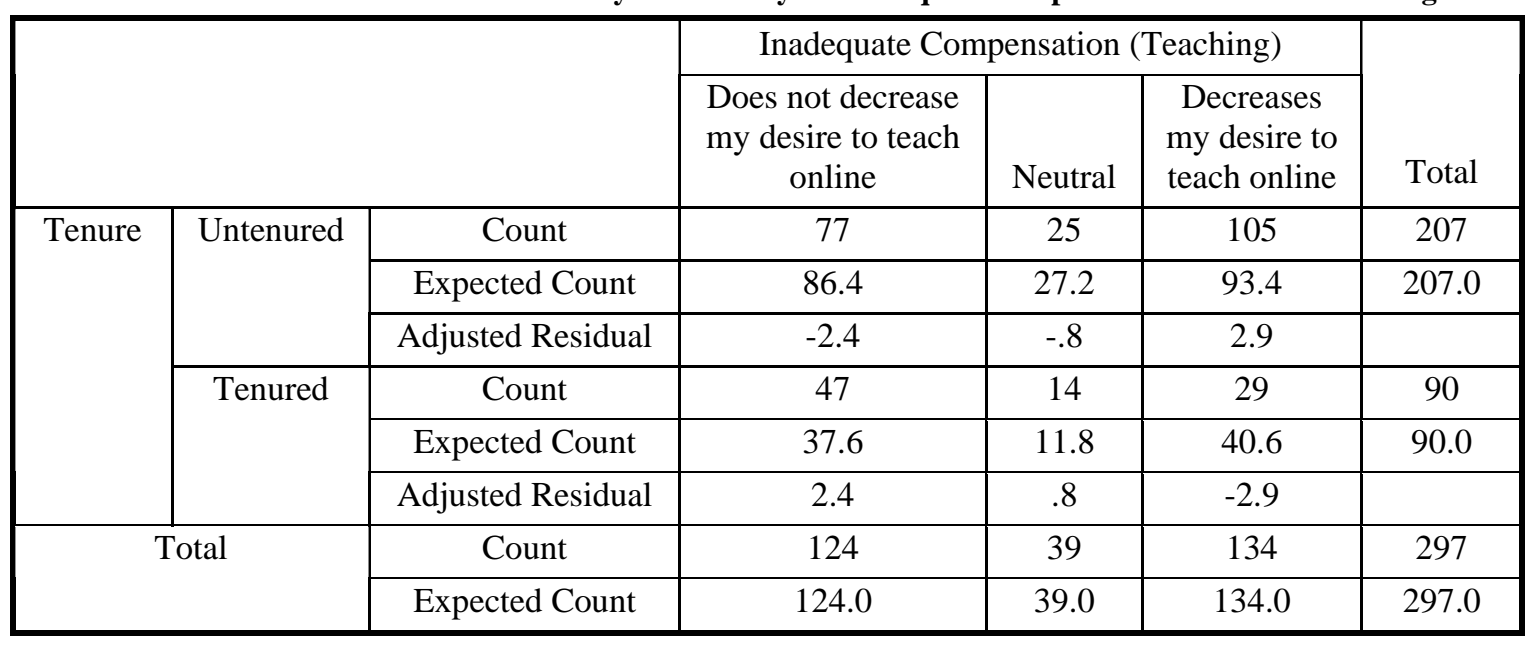

Chi-Square Tests

\begin{tabular}{|c|c|c|c|}
\hline & Value & df & $\begin{array}{c}\text { Asymp. Sig. } \\
\text { (2-sided) }\end{array}$ \\
\hline Pearson Chi-Square & $8.729(\mathrm{a})$ & 2 & .013 \\
\hline Likelihood Ratio & 8.889 & 2 & .012 \\
\hline $\begin{array}{c}\text { Linear-by-Linear } \\
\text { Association }\end{array}$ & 8.100 & 1 & .004 \\
\hline N of Valid Cases & 297 & & \\
\hline
\end{tabular}

(a) 0 cells $(.0 \%)$ have expected count less than 5 . The minimum expected count is 11.82 . 
Bridges and Barriers to Teaching Online College Courses:

A Study of Experienced Online Faculty in Thirty-six Colleges

Table 37: Tenured v. Untenured Faculty: There may be inadequate compensation for online course revision.

\begin{tabular}{|c|c|c|c|c|c|c|}
\hline & & & \multicolumn{3}{|c|}{ Inadequate Compensation (Revision) } & \multirow[b]{2}{*}{ Total } \\
\hline & & & $\begin{array}{l}\text { Does not decrease } \\
\text { my desire to teach } \\
\text { online }\end{array}$ & Neutral & $\begin{array}{c}\text { Decreases } \\
\text { my desire to } \\
\text { teach online }\end{array}$ & \\
\hline \multirow[t]{6}{*}{ Tenure } & \multirow[t]{3}{*}{ Untenured } & Count & 76 & 26 & 106 & 208 \\
\hline & & Expected Count & 82.1 & 30.8 & 95.1 & 208.0 \\
\hline & & Adjusted Residual & -1.5 & -1.7 & 2.7 & \\
\hline & \multirow[t]{3}{*}{ Tenured } & Count & 44 & 19 & 33 & 96 \\
\hline & & Expected Count & 37.9 & 14.2 & 43.9 & 96.0 \\
\hline & & Adjusted Residual & 1.5 & 1.7 & -2.7 & \\
\hline \multirow{2}{*}{\multicolumn{2}{|c|}{ Total }} & Count & 120 & 45 & 139 & 304 \\
\hline & & Expected Count & 120.0 & 45.0 & 139.0 & 304.0 \\
\hline
\end{tabular}

Chi-Square Tests

\begin{tabular}{|c|c|c|c|}
\hline & Value & df & $\begin{array}{c}\text { Asymp. Sig. } \\
\text { (2-sided) }\end{array}$ \\
\hline Pearson Chi-Square & $7.749(\mathrm{a})$ & 2 & .021 \\
\hline Likelihood Ratio & 7.809 & 2 & .020 \\
\hline $\begin{array}{c}\text { Linear-by-Linear } \\
\text { Association }\end{array}$ & 5.171 & 1 & .023 \\
\hline N of Valid Cases & 304 & & \\
\hline
\end{tabular}

(a) 0 cells (.0\%) have expected count less than 5 . The minimum expected count is 14.21 .

Table 38: Full Time/Traditional v. Part Time/Non-Traditional: Online teaching may take more time than classroom teaching.

\begin{tabular}{|c|c|c|c|c|c|c|}
\hline & \multicolumn{3}{|c|}{ More Time } & \multirow[b]{2}{*}{ Total } \\
\hline & & & $\begin{array}{l}\text { Does not decrease } \\
\text { my desire to teach } \\
\text { online }\end{array}$ & Neutral & $\begin{array}{l}\text { Decreases } \\
\text { my desire to } \\
\text { teach online }\end{array}$ & \\
\hline \multirow{6}{*}{$\begin{array}{l}\text { Full Time - } \\
\text { Part Time }\end{array}$} & \multirow{3}{*}{$\begin{array}{l}\text { Part Time - Non- } \\
\text { traditional }\end{array}$} & Count & 95 & 21 & 52 & 168 \\
\hline & & Expected Count & 82.7 & 21.2 & 64.1 & 168.0 \\
\hline & & Adjusted Residual & 2.8 & -.1 & -2.8 & \\
\hline & \multirow[t]{3}{*}{ Full Time - Traditional } & Count & 61 & 19 & 69 & 149 \\
\hline & & Expected Count & 73.3 & 18.8 & 56.9 & 149.0 \\
\hline & & Adjusted Residual & -2.8 & .1 & 2.8 & \\
\hline \multirow{2}{*}{\multicolumn{2}{|c|}{ Total }} & Count & 156 & 40 & 121 & 317 \\
\hline & & Expected Count & 156.0 & 40.0 & 121.0 & 317.0 \\
\hline
\end{tabular}


Bridges and Barriers to Teaching Online College Courses:

A Study of Experienced Online Faculty in Thirty-six Colleges

Chi-Square Tests

\begin{tabular}{|c|c|c|c|}
\hline & Value & df & $\begin{array}{c}\text { Asymp. Sig. } \\
\text { (2-sided) }\end{array}$ \\
\hline Pearson Chi-Square & $8.791(\mathrm{a})$ & 2 & .012 \\
\hline Likelihood Ratio & 8.827 & 2 & .012 \\
\hline $\begin{array}{c}\text { Linear-by-Linear } \\
\text { Association }\end{array}$ & 8.759 & 1 & .003 \\
\hline N of Valid Cases & 317 & & \\
\hline
\end{tabular}

(a) 0 cells (.0\%) have expected count less than 5 . The minimum expected count is 18.80 .

Table 39: Online Teaching Experience: Absence of Face-Face Interaction

\begin{tabular}{|c|c|c|c|c|c|c|}
\hline & & & \multicolumn{3}{|c|}{ Absence of Face-to-Face Interaction } & \multirow[b]{2}{*}{ Total } \\
\hline & & & $\begin{array}{c}\text { Does not decrease } \\
\text { my desire to teach } \\
\text { online }\end{array}$ & Neutral & $\begin{array}{c}\text { Decreases } \\
\text { my desire to } \\
\text { teach online }\end{array}$ & \\
\hline \multirow[t]{6}{*}{ Experience } & \multirow[t]{3}{*}{ One or two times } & Count & 34 & 17 & 33 & 84 \\
\hline & & Expected Count & 44.4 & 12.4 & 27.2 & 84.0 \\
\hline & & Adjusted Residual & -2.6 & 1.6 & 1.6 & \\
\hline & \multirow[t]{3}{*}{ Three or more times } & Count & 134 & 30 & 70 & 234 \\
\hline & & Expected Count & 123.6 & 34.6 & 75.8 & 234.0 \\
\hline & & Adjusted Residual & 2.6 & -1.6 & -1.6 & \\
\hline \multirow{2}{*}{\multicolumn{2}{|c|}{ Total }} & Count & 168 & 47 & 103 & 318 \\
\hline & & Expected Count & 168.0 & 47.0 & 103.0 & 318.0 \\
\hline
\end{tabular}

\section{Chi-Square Tests}

\begin{tabular}{|c|c|c|c|}
\hline & Value & df & $\begin{array}{c}\text { Asymp. Sig. } \\
\text { (2-sided) }\end{array}$ \\
\hline Pearson Chi-Square & $7.275(\mathrm{a})$ & 2 & .026 \\
\hline Likelihood Ratio & 7.251 & 2 & .027 \\
\hline $\begin{array}{c}\text { Linear-by-Linear } \\
\text { Association }\end{array}$ & 5.203 & 1 & .023 \\
\hline N of Valid Cases & 318 & & \\
\hline
\end{tabular}

(a) 0 cells (.0\%) have expected count less than 5 . The minimum expected count is 12.42 . 
Bridges and Barriers to Teaching Online College Courses:

A Study of Experienced Online Faculty in Thirty-six Colleges

Table 40: Online Teaching Experience: Effective pedagogy for online teaching may be unfamiliar.

\begin{tabular}{|c|c|c|c|c|c|c|}
\hline & & & \multicolumn{3}{|c|}{ Unfamiliar Effective Pedagogy } & \multirow[b]{2}{*}{ Total } \\
\hline & & & $\begin{array}{c}\text { Does not } \\
\text { decrease my } \\
\text { desire to teach } \\
\text { online }\end{array}$ & Neutral & $\begin{array}{l}\text { Decreases my } \\
\text { desire to } \\
\text { teach online }\end{array}$ & \\
\hline \multirow[t]{6}{*}{ Experience } & \multirow[t]{3}{*}{ One or two times } & Count & 48 & 16 & 21 & 85 \\
\hline & & Expected Count & 55.1 & 14.9 & 14.9 & 85.0 \\
\hline & & Adjusted Residual & -1.9 & .4 & 2.0 & \\
\hline & \multirow[t]{3}{*}{ Three or more times } & Count & 155 & 39 & 34 & 228 \\
\hline & & Expected Count & 147.9 & 40.1 & 40.1 & 228.0 \\
\hline & & Adjusted Residual & 1.9 & -.4 & -2.0 & \\
\hline \multirow{2}{*}{\multicolumn{2}{|c|}{ Total }} & Count & 203 & 55 & 55 & 313 \\
\hline & & Expected Count & 203.0 & 55.0 & 55.0 & 313.0 \\
\hline
\end{tabular}

Chi-Square Tests

\begin{tabular}{|c|c|c|c|}
\hline & Value & $\mathrm{df}$ & $\begin{array}{c}\text { Asymp. Sig. } \\
\text { (2-sided) }\end{array}$ \\
\hline Pearson Chi-Square & $4.749(\mathrm{a})$ & 2 & .093 \\
\hline Likelihood Ratio & 4.556 & 2 & .102 \\
\hline $\begin{array}{c}\text { Linear-by-Linear } \\
\text { Association }\end{array}$ & 4.664 & 1 & .031 \\
\hline N of Valid Cases & 313 & & \\
\hline
\end{tabular}

(a) 0 cells $(.0 \%)$ have expected count less than 5 . The minimum expected count is 14.94 .

Table 41: Online Teaching Experience: There may be little or no opportunity to observe other faculty using technology for online teaching prior to committing to teach online.

\begin{tabular}{|c|c|c|c|c|c|c|}
\hline & \multicolumn{3}{|c|}{ Little or No Opportunity to Observe } & \multirow[b]{2}{*}{ Total } \\
\hline & & & $\begin{array}{l}\text { Does not decrease } \\
\text { my desire to teach } \\
\text { online }\end{array}$ & Neutral & $\begin{array}{l}\text { Decreases } \\
\text { my desire to } \\
\text { teach online }\end{array}$ & \\
\hline \multirow[t]{6}{*}{ Experience } & \multirow[t]{3}{*}{ One or two times } & Count & 42 & 12 & 30 & 84 \\
\hline & & Expected Count & 48.4 & 14.5 & 21.1 & 84.0 \\
\hline & & Adjusted Residual & -1.7 & -.8 & 2.6 & \\
\hline & \multirow[t]{3}{*}{ Three or more times } & Count & 132 & 40 & 46 & 218 \\
\hline & & Expected Count & 125.6 & 37.5 & 54.9 & 218.0 \\
\hline & & Adjusted Residual & 1.7 & .8 & -2.6 & \\
\hline \multirow{2}{*}{\multicolumn{2}{|c|}{ Total }} & Count & 174 & 52 & 76 & 302 \\
\hline & & Expected Count & 174.0 & 52.0 & 76.0 & 302.0 \\
\hline
\end{tabular}


Bridges and Barriers to Teaching Online College Courses: A Study of Experienced Online Faculty in Thirty-six Colleges

Chi-Square Tests

\begin{tabular}{|c|c|c|c|}
\hline & Value & $\mathrm{df}$ & $\begin{array}{c}\text { Asymp. Sig. } \\
\text { (2-sided) }\end{array}$ \\
\hline Pearson Chi-Square & $6.898(\mathrm{a})$ & 2 & .032 \\
\hline Likelihood Ratio & 6.608 & 2 & .037 \\
\hline $\begin{array}{c}\text { Linear-by-Linear } \\
\text { Association }\end{array}$ & 5.297 & 1 & .021 \\
\hline $\begin{array}{c}\text { N of Valid Cases } \\
\text { N of }\end{array}$ & 302 & & \\
\hline
\end{tabular}

(a) 0 cells $(.0 \%)$ have expected count less than 5 . The minimum expected count is 14.46 .

Table 42: Online Teaching Experience: There may be little or no opportunity to experiment with the technology for teaching online prior to committing to teach online.

\begin{tabular}{|c|c|c|c|c|c|c|}
\hline & & & \multicolumn{3}{|c|}{$\begin{array}{c}\text { No Opportunity to Experiment with } \\
\text { Technology }\end{array}$} & \multirow[b]{2}{*}{ Total } \\
\hline & & & $\begin{array}{c}\text { Does not decrease } \\
\text { my desire to teach } \\
\text { online }\end{array}$ & Neutral & $\begin{array}{c}\text { Decreases } \\
\text { my desire to } \\
\text { teach online }\end{array}$ & \\
\hline \multirow[t]{6}{*}{ Experience } & \multirow[t]{3}{*}{ One or two times } & Count & 42 & 9 & 31 & 82 \\
\hline & & Expected Count & 45.8 & 13.4 & 22.8 & 82.0 \\
\hline & & Adjusted Residual & -1.0 & -1.5 & 2.4 & \\
\hline & \multirow[t]{3}{*}{ Three or more times } & Count & 129 & 41 & 54 & 224 \\
\hline & & Expected Count & 125.2 & 36.6 & 62.2 & 224.0 \\
\hline & & Adjusted Residual & 1.0 & 1.5 & -2.4 & \\
\hline \multirow{2}{*}{\multicolumn{2}{|c|}{ Total }} & Count & 171 & 50 & 85 & 306 \\
\hline & & Expected Count & 171.0 & 50.0 & 85.0 & 306.0 \\
\hline
\end{tabular}

Chi-Square Tests

\begin{tabular}{|c|c|c|c|}
\hline & Value & $\mathrm{df}$ & $\begin{array}{c}\text { Asymp. Sig. } \\
\text { (2-sided) }\end{array}$ \\
\hline Pearson Chi-Square & $6.463(\mathrm{a})$ & 2 & .039 \\
\hline Likelihood Ratio & 6.389 & 2 & .041 \\
\hline $\begin{array}{c}\text { Linear-by-Linear } \\
\text { Association }\end{array}$ & 3.180 & 1 & .075 \\
\hline N of Valid Cases & 306 & & \\
\hline
\end{tabular}

(a) 0 cells (.0\%) have expected count less than 5 . The minimum expected count is 13.40 . 
Bridges and Barriers to Teaching Online College Courses:

A Study of Experienced Online Faculty in Thirty-six Colleges

Table 43: Online Teaching Experience: There may be inadequate time to learn about online teaching

\begin{tabular}{|c|c|c|c|c|c|c|}
\hline & & & \multicolumn{3}{|c|}{ Inadequate Time to Learn } & \multirow[b]{2}{*}{ Total } \\
\hline & & & $\begin{array}{c}\text { Does not decrease } \\
\text { my desire to teach } \\
\text { online }\end{array}$ & Neutral & $\begin{array}{c}\text { Decreases } \\
\text { my desire to } \\
\text { teach online }\end{array}$ & \\
\hline \multirow[t]{6}{*}{ Experience } & \multirow[t]{3}{*}{ One or two times } & Count & 46 & 5 & 29 & 80 \\
\hline & & Expected Count & 45.5 & 11.0 & 23.4 & 80.0 \\
\hline & & Adjusted Residual & .1 & -2.3 & 1.6 & \\
\hline & \multirow[t]{3}{*}{ Three or more times } & Count & 119 & 35 & 56 & 210 \\
\hline & & Expected Count & 119.5 & 29.0 & 61.6 & 210.0 \\
\hline & & Adjusted Residual & -.1 & 2.3 & -1.6 & \\
\hline \multirow{2}{*}{\multicolumn{2}{|c|}{ Total }} & Count & 165 & 40 & 85 & 290 \\
\hline & & Expected Count & 165.0 & 40.0 & 85.0 & 290.0 \\
\hline
\end{tabular}

Chi-Square Tests

\begin{tabular}{|c|c|c|c|}
\hline & Value & df & $\begin{array}{c}\text { Asymp. Sig. } \\
\text { (2-sided) }\end{array}$ \\
\hline Pearson Chi-Square & $6.380(\mathrm{a})$ & 2 & .041 \\
\hline Likelihood Ratio & 7.076 & 2 & .029 \\
\hline $\begin{array}{c}\text { Linear-by-Linear } \\
\text { Association }\end{array}$ & .562 & 1 & .453 \\
\hline N of Valid Cases & 290 & & \\
\hline
\end{tabular}

(a) 0 cells $(.0 \%)$ have expected count less than 5 . The minimum expected count is 11.03 .

Table 44: Online Teaching Experience: There may be inadequate compensation for online course development.

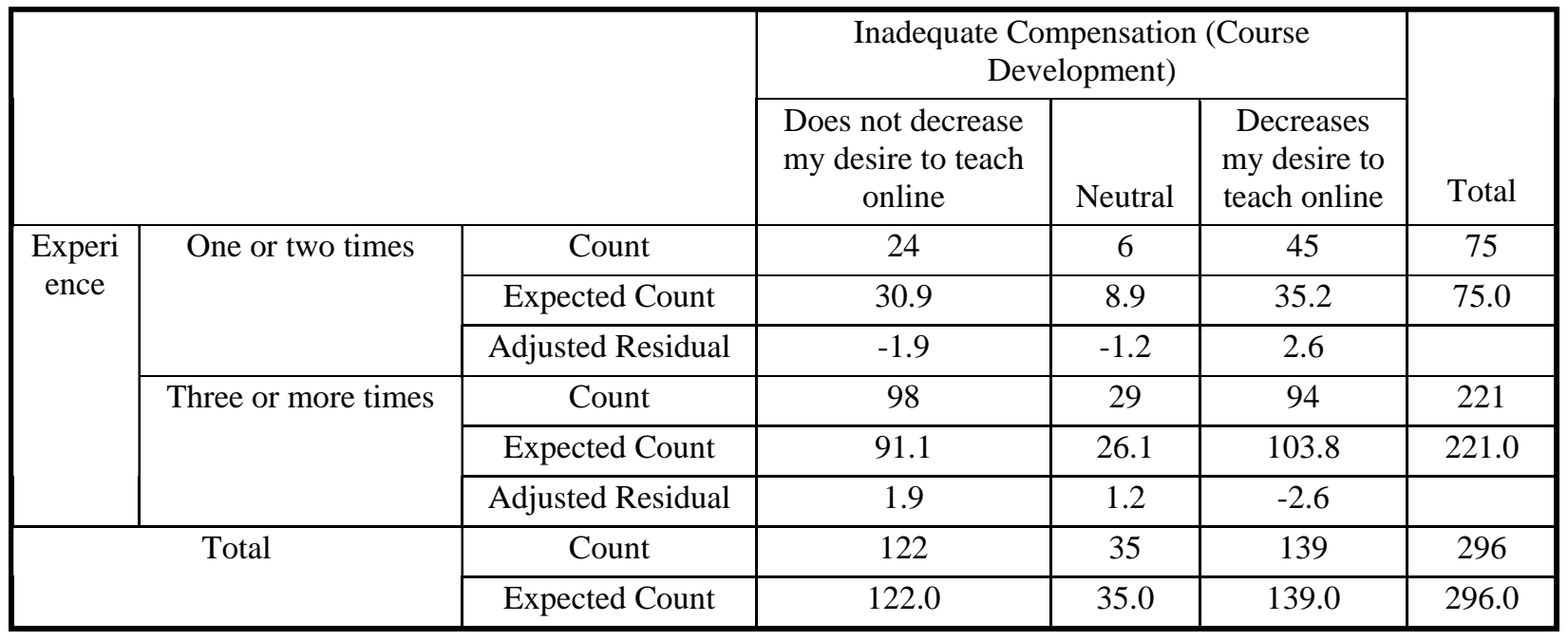


Bridges and Barriers to Teaching Online College Courses:

A Study of Experienced Online Faculty in Thirty-six Colleges

Chi-Square Tests

\begin{tabular}{|c|c|c|c|}
\hline & Value & df & $\begin{array}{c}\text { Asymp. Sig. } \\
\text { (2-sided) }\end{array}$ \\
\hline Pearson Chi-Square & $6.950(\mathrm{a})$ & 2 & .031 \\
\hline Likelihood Ratio & 6.986 & 2 & .030 \\
\hline $\begin{array}{c}\text { Linear-by-Linear } \\
\text { Association }\end{array}$ & 5.645 & 1 & .018 \\
\hline N of Valid Cases & 296 & & \\
\hline
\end{tabular}

(a) 0 cells (.0\%) have expected count less than 5 . The minimum expected count is 8.87 .

Table 45: Online Teaching Experience: There may be inadequate compensation for online teaching.

\begin{tabular}{|c|c|c|c|c|c|c|}
\hline & & & \multicolumn{3}{|c|}{ Inadequate Compensation (Teaching) } & \multirow[b]{2}{*}{ Total } \\
\hline & & & $\begin{array}{l}\text { Does not decrease } \\
\text { my desire to teach } \\
\text { online }\end{array}$ & Neutral & $\begin{array}{c}\text { Decreases } \\
\text { my desire to } \\
\text { teach online }\end{array}$ & \\
\hline \multirow[t]{6}{*}{ Experience } & \multirow[t]{3}{*}{ One or two times } & Count & 26 & 8 & 45 & 79 \\
\hline & & Expected Count & 32.9 & 10.3 & 35.8 & 79.0 \\
\hline & & Adjusted Residual & -1.8 & -.9 & 2.4 & \\
\hline & \multirow{3}{*}{$\begin{array}{c}\text { Three or more } \\
\text { times }\end{array}$} & Count & 99 & 31 & 91 & 221 \\
\hline & & Expected Count & 92.1 & 28.7 & 100.2 & 221.0 \\
\hline & & Adjusted Residual & 1.8 & .9 & -2.4 & \\
\hline \multirow{2}{*}{\multicolumn{2}{|c|}{ Total }} & Count & 125 & 39 & 136 & 300 \\
\hline & & Expected Count & 125.0 & 39.0 & 136.0 & 300.0 \\
\hline
\end{tabular}

Chi-Square Tests

\begin{tabular}{|c|c|c|c|}
\hline & Value & df & $\begin{array}{c}\text { Asymp. Sig. } \\
\text { (2-sided) }\end{array}$ \\
\hline Pearson Chi-Square & $5.853(\mathrm{a})$ & 2 & .054 \\
\hline Likelihood Ratio & 5.840 & 2 & .054 \\
\hline $\begin{array}{c}\text { Linear-by-Linear } \\
\text { Association }\end{array}$ & 5.113 & 1 & .024 \\
\hline N of Valid Cases & 300 & & \\
\hline
\end{tabular}

(a) 0 cells (.0\%) have expected count less than 5 . The minimum expected count is 10.27 . 
Bridges and Barriers to Teaching Online College Courses:

A Study of Experienced Online Faculty in Thirty-six Colleges

Table 46: Online Teaching Experience: Concerns that offering online education can reduce an institutions reputation.

\begin{tabular}{|c|c|c|c|c|c|c|}
\hline & & & \multicolumn{3}{|c|}{ Reduce Institution's Reputation } & \multirow[b]{2}{*}{ Total } \\
\hline & & & $\begin{array}{c}\text { Does not decrease } \\
\text { my desire to teach } \\
\text { online }\end{array}$ & Neutral & $\begin{array}{c}\text { Decreases } \\
\text { my desire to } \\
\text { teach online }\end{array}$ & \\
\hline \multirow[t]{6}{*}{ Experience } & \multirow[t]{3}{*}{ One or two times } & Count & 49 & 6 & 22 & 77 \\
\hline & & Expected Count & 49.4 & 11.5 & 16.1 & 77.0 \\
\hline & & Adjusted Residual & -.1 & -2.0 & 1.9 & \\
\hline & \multirow{3}{*}{$\begin{array}{c}\text { Three or more } \\
\text { times }\end{array}$} & Count & 144 & 39 & 41 & 224 \\
\hline & & Expected Count & 143.6 & 33.5 & 46.9 & 224.0 \\
\hline & & Adjusted Residual & .1 & 2.0 & -1.9 & \\
\hline \multirow{2}{*}{\multicolumn{2}{|c|}{ Total }} & Count & 193 & 45 & 63 & 301 \\
\hline & & Expected Count & 193.0 & 45.0 & 63.0 & 301.0 \\
\hline
\end{tabular}

Chi-Square Tests

\begin{tabular}{|c|c|c|c|}
\hline & Value & $\mathrm{df}$ & $\begin{array}{c}\text { Asymp. Sig. } \\
\text { (2-sided) }\end{array}$ \\
\hline Pearson Chi-Square & $6.436(\mathrm{a})$ & 2 & .040 \\
\hline Likelihood Ratio & 6.766 & 2 & .034 \\
\hline $\begin{array}{c}\text { Linear-by-Linear } \\
\text { Association }\end{array}$ & 1.025 & 1 & .311 \\
\hline N of Valid Cases & 301 & & \\
\hline
\end{tabular}

(a) 0 cells $(.0 \%)$ have expected count less than 5 . The minimum expected count is 11.51 .

Table 47: Voluntariness: The technology involved in online teaching can be confusing.

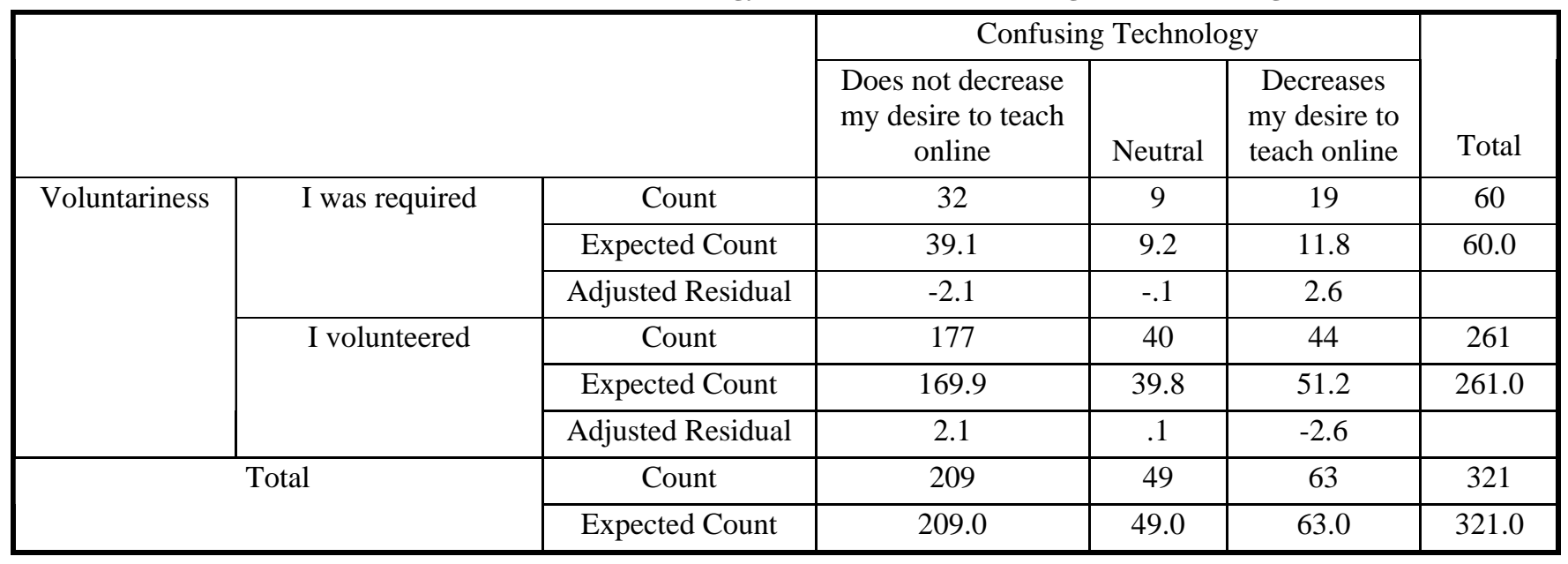


Bridges and Barriers to Teaching Online College Courses:

A Study of Experienced Online Faculty in Thirty-six Colleges

Chi-Square Tests

\begin{tabular}{|c|c|c|c|}
\hline & Value & df & $\begin{array}{c}\text { Asymp. Sig. } \\
\text { (2-sided) }\end{array}$ \\
\hline Pearson Chi-Square & $7.026(\mathrm{a})$ & 2 & .030 \\
\hline Likelihood Ratio & 6.457 & 2 & .040 \\
\hline $\begin{array}{c}\text { Linear-by-Linear } \\
\text { Association }\end{array}$ & 6.515 & 1 & .011 \\
\hline N of Valid Cases & 321 & & \\
\hline
\end{tabular}

(a) 0 cells (.0\%) have expected count less than 5 . The minimum expected count is 9.16 .

Table 48: Voluntariness: The absence of face-to-face interaction with students can be a disadvantage.

\begin{tabular}{|c|c|c|c|c|c|c|}
\hline & & & \multicolumn{3}{|c|}{ Absence of Face-to-Face Interaction } & \multirow[b]{2}{*}{ Total } \\
\hline & & & $\begin{array}{c}\text { Does not } \\
\text { decrease my } \\
\text { desire to teach } \\
\text { online }\end{array}$ & Neutral & $\begin{array}{l}\text { Decreases } \\
\text { my desire to } \\
\text { teach online }\end{array}$ & \\
\hline \multirow[t]{6}{*}{ Voluntariness 1} & \multirow[t]{3}{*}{ I was required } & Count & 26 & 4 & 27 & 57 \\
\hline & & Expected Count & 30.0 & 8.4 & 18.6 & 57.0 \\
\hline & & Adjusted Residual & -1.2 & -1.8 & 2.6 & \\
\hline & \multirow[t]{3}{*}{ I volunteered } & Count & 142 & 43 & 77 & 262 \\
\hline & & Expected Count & 138.0 & 38.6 & 85.4 & 262.0 \\
\hline & & Adjusted Residual & 1.2 & 1.8 & -2.6 & \\
\hline \multirow{2}{*}{\multicolumn{2}{|c|}{ Total }} & Count & 168 & 47 & 104 & 319 \\
\hline & & Expected Count & 168.0 & 47.0 & 104.0 & 319.0 \\
\hline
\end{tabular}

Chi-Square Tests

\begin{tabular}{|c|c|c|c|}
\hline & Value & df & $\begin{array}{c}\text { Asymp. Sig. } \\
\text { (2-sided) }\end{array}$ \\
\hline Pearson Chi-Square & $8.101(\mathrm{a})$ & 2 & .017 \\
\hline Likelihood Ratio & 8.223 & 2 & .016 \\
\hline $\begin{array}{c}\text { Linear-by-Linear } \\
\text { Association }\end{array}$ & 4.053 & 1 & .044 \\
\hline N of Valid Cases & 319 & & \\
\hline
\end{tabular}

(a) 0 cells (.0\%) have expected count less than 5 . The minimum expected count is 8.40 . 
Bridges and Barriers to Teaching Online College Courses:

A Study of Experienced Online Faculty in Thirty-six Colleges

Table 49: Voluntariness: Students may lack adequate access to participate effectively in online courses.

\begin{tabular}{|c|c|c|c|c|c|c|}
\hline & & & \multicolumn{3}{|c|}{ Students Lack Adequate Access } & \multirow[b]{2}{*}{ Total } \\
\hline & & & $\begin{array}{l}\text { Does not decrease } \\
\text { my desire to teach } \\
\text { online }\end{array}$ & Neutral & $\begin{array}{c}\text { Decreases } \\
\text { my desire to } \\
\text { teach online }\end{array}$ & \\
\hline \multirow[t]{6}{*}{ Voluntariness 1} & \multirow[t]{3}{*}{ I was required } & Count & 20 & 5 & 31 & 56 \\
\hline & & Expected Count & 24.8 & 9.3 & 21.9 & 56.0 \\
\hline & & Adjusted Residual & -1.4 & -1.7 & 2.7 & \\
\hline & \multirow[t]{3}{*}{ I volunteered } & Count & 119 & 47 & 92 & 258 \\
\hline & & Expected Count & 114.2 & 42.7 & 101.1 & 258.0 \\
\hline & & Adjusted Residual & 1.4 & 1.7 & -2.7 & \\
\hline \multirow{2}{*}{\multicolumn{2}{|c|}{ Total }} & Count & 139 & 52 & 123 & 314 \\
\hline & & Expected Count & 139.0 & 52.0 & 123.0 & 314.0 \\
\hline
\end{tabular}

Chi-Square Tests

\begin{tabular}{|c|c|c|c|}
\hline & Value & df & $\begin{array}{c}\text { Asymp. Sig. } \\
\text { (2-sided) }\end{array}$ \\
\hline Pearson Chi-Square & $8.081(\mathrm{a})$ & 2 & .018 \\
\hline Likelihood Ratio & 8.127 & 2 & .017 \\
\hline $\begin{array}{c}\text { Linear-by-Linear } \\
\text { Association }\end{array}$ & 4.998 & 1 & .025 \\
\hline N of Valid Cases & 314 & & \\
\hline
\end{tabular}

(a) 0 cells $(.0 \%)$ have expected count less than 5 . The minimum expected count is 9.27 .

Table 50: Voluntariness: There may be little or no opportunity to experiment with the technology for teaching online prior to committing to teach online.

\begin{tabular}{|c|c|c|c|c|c|c|}
\hline & & & \multicolumn{3}{|c|}{$\begin{array}{c}\text { No Opportunity to Experiment with } \\
\text { Technology }\end{array}$} & \multirow[b]{2}{*}{ Total } \\
\hline & & & $\begin{array}{c}\text { Does not decrease } \\
\text { my desire to teach } \\
\text { online }\end{array}$ & Neutral & $\begin{array}{c}\text { Decreases } \\
\text { my desire to } \\
\text { teach online }\end{array}$ & \\
\hline \multirow[t]{6}{*}{ Voluntariness 1} & \multirow[t]{3}{*}{ I was asked/required } & Count & 24 & 7 & 24 & 55 \\
\hline & & Expected Count & 30.6 & 9.1 & 15.2 & 55.0 \\
\hline & & Adjusted Residual & -2.0 & -.9 & 2.9 & \\
\hline & \multirow[t]{3}{*}{ I volunteered } & Count & 147 & 44 & 61 & 252 \\
\hline & & Expected Count & 140.4 & 41.9 & 69.8 & 252.0 \\
\hline & & Adjusted Residual & 2.0 & .9 & -2.9 & \\
\hline \multirow{2}{*}{\multicolumn{2}{|c|}{ Total }} & Count & 171 & 51 & 85 & 307 \\
\hline & & Expected Count & 171.0 & 51.0 & 85.0 & 307.0 \\
\hline
\end{tabular}


Bridges and Barriers to Teaching Online College Courses: A Study of Experienced Online Faculty in Thirty-six Colleges

Chi-Square Tests

\begin{tabular}{|c|c|c|c|}
\hline & Value & df & $\begin{array}{c}\text { Asymp. Sig. } \\
\text { (2-sided) }\end{array}$ \\
\hline Pearson Chi-Square & $8.515(\mathrm{a})$ & 2 & .014 \\
\hline Likelihood Ratio & 7.958 & 2 & .019 \\
\hline $\begin{array}{c}\text { Linear-by-Linear } \\
\text { Association }\end{array}$ & 6.938 & 1 & .008 \\
\hline N of Valid Cases & 307 & & \\
\hline
\end{tabular}

(a) 0 cells (.0\%) have expected count less than 5 . The minimum expected count is 9.14 .

Table 51: Voluntariness: Inadequate time to learn about online teaching

\begin{tabular}{|c|c|c|c|c|c|c|}
\hline & & & \multicolumn{3}{|c|}{ Inadequate Time to Learn } & \multirow[b]{2}{*}{ Total } \\
\hline & & & $\begin{array}{l}\text { Does not decrease } \\
\text { my desire to teach } \\
\text { online }\end{array}$ & Neutral & $\begin{array}{c}\text { Decreases } \\
\text { my desire to } \\
\text { teach online }\end{array}$ & \\
\hline \multirow[t]{6}{*}{ Voluntariness 1} & \multirow[t]{3}{*}{ I was asked/required } & Count & 19 & 10 & 23 & 52 \\
\hline & & Expected Count & 29.5 & 7.3 & 15.2 & 52.0 \\
\hline & & Adjusted Residual & -3.2 & 1.2 & 2.6 & \\
\hline & \multirow[t]{3}{*}{ I volunteered } & Count & 146 & 31 & 62 & 239 \\
\hline & & Expected Count & 135.5 & 33.7 & 69.8 & 239.0 \\
\hline & & Adjusted Residual & 3.2 & -1.2 & -2.6 & \\
\hline \multirow{2}{*}{\multicolumn{2}{|c|}{ Total }} & Count & 165 & 41 & 85 & 291 \\
\hline & & Expected Count & 165.0 & 41.0 & 85.0 & 291.0 \\
\hline
\end{tabular}

\section{Chi-Square Tests}

\begin{tabular}{|c|c|c|c|}
\hline & Value & df & $\begin{array}{c}\text { Asymp. Sig. } \\
\text { (2-sided) }\end{array}$ \\
\hline Pearson Chi-Square & $10.618(\mathrm{a})$ & 2 & .005 \\
\hline Likelihood Ratio & 10.528 & 2 & .005 \\
\hline $\begin{array}{c}\text { Linear-by-Linear } \\
\text { Association }\end{array}$ & 9.969 & 1 & .002 \\
\hline N of Valid Cases & 291 & & \\
\hline
\end{tabular}

(a) 0 cells (.0\%) have expected count less than 5 . The minimum expected count is 7.33 . 
Bridges and Barriers to Teaching Online College Courses:

A Study of Experienced Online Faculty in Thirty-six Colleges

Table 52: Voluntariness: Inadequate time to develop a new online course

\begin{tabular}{|c|c|c|c|c|c|}
\hline \multicolumn{2}{|c|}{} & \multicolumn{2}{|c|}{$\begin{array}{c}\text { Inadequate Time to Develop A New Online } \\
\text { Course }\end{array}$} & $\begin{array}{c}\text { Decreases } \\
\text { my desire to } \\
\text { teach online }\end{array}$ \\
\cline { 3 - 7 } Total \\
\cline { 3 - 7 }
\end{tabular}

Chi-Square Tests

\begin{tabular}{|c|c|c|c|}
\hline & Value & df & $\begin{array}{c}\text { Asymp. Sig. } \\
\text { (2-sided) }\end{array}$ \\
\hline Pearson Chi-Square & $8.646(\mathrm{a})$ & 2 & .013 \\
\hline Likelihood Ratio & 8.702 & 2 & .013 \\
\hline $\begin{array}{c}\text { Linear-by-Linear } \\
\text { Association }\end{array}$ & 8.591 & 1 & .003 \\
\hline N of Valid Cases & 288 & & \\
\hline
\end{tabular}

(a) 0 cells $(.0 \%)$ have expected count less than 5 . The minimum expected count is 6.38 .

Table 53: Voluntariness: The campus administration may not recognize the effort required to teach online.

\begin{tabular}{|c|c|c|c|c|c|c|}
\hline & & & \multicolumn{3}{|c|}{ Not Recognized by Campus Administration } & \multirow[b]{2}{*}{ Total } \\
\hline & & & $\begin{array}{c}\text { Does not decrease } \\
\text { my desire to teach } \\
\text { online }\end{array}$ & Neutral & $\begin{array}{c}\text { Decreases } \\
\text { my desire to } \\
\text { teach online }\end{array}$ & \\
\hline \multirow[t]{6}{*}{ Voluntariness 1} & \multirow[t]{3}{*}{ I was required } & Count & 16 & 11 & 27 & 54 \\
\hline & & Expected Count & 24.5 & 6.5 & 23.0 & 54.0 \\
\hline & & Adjusted Residual & -2.6 & 2.1 & 1.2 & \\
\hline & \multirow[t]{3}{*}{ I volunteered } & Count & 115 & 24 & 96 & 235 \\
\hline & & Expected Count & 106.5 & 28.5 & 100.0 & 235.0 \\
\hline & & Adjusted Residual & 2.6 & -2.1 & -1.2 & \\
\hline \multirow{2}{*}{\multicolumn{2}{|c|}{ Total }} & Count & 131 & 35 & 123 & 289 \\
\hline & & Expected Count & 131.0 & 35.0 & 123.0 & 289.0 \\
\hline
\end{tabular}


Bridges and Barriers to Teaching Online College Courses:

A Study of Experienced Online Faculty in Thirty-six Colleges

Chi-Square Tests

\begin{tabular}{|c|c|c|c|}
\hline & Value & df & $\begin{array}{c}\text { Asymp. Sig. } \\
\text { (2-sided) }\end{array}$ \\
\hline Pearson Chi-Square & $8.215(\mathrm{a})$ & 2 & .016 \\
\hline Likelihood Ratio & 8.093 & 2 & .017 \\
\hline $\begin{array}{c}\text { Linear-by-Linear } \\
\text { Association }\end{array}$ & 4.035 & 1 & .045 \\
\hline N of Valid Cases & 289 & & \\
\hline
\end{tabular}

(a) 0 cells $(.0 \%)$ have expected count less than 5 . The minimum expected count is 6.54 .

Table 54: Voluntariness: Some people say that online courses are of an inferior quality compared to classroom-based courses.

\begin{tabular}{|c|c|c|c|c|c|c|}
\hline & & & \multicolumn{3}{|c|}{ Inferior Quality } & \multirow[b]{2}{*}{ Total } \\
\hline & & & $\begin{array}{c}\text { Does not decrease } \\
\text { my desire to teach } \\
\text { online }\end{array}$ & Neutral & $\begin{array}{c}\text { Decreases } \\
\text { my desire to } \\
\text { teach online }\end{array}$ & \\
\hline \multirow[t]{6}{*}{ Voluntariness 1} & \multirow[t]{3}{*}{ I was required } & Count & 27 & 12 & 18 & 57 \\
\hline & & Expected Count & 35.8 & 7.6 & 13.7 & 57.0 \\
\hline & & Adjusted Residual & -2.7 & 1.9 & 1.5 & \\
\hline & \multirow[t]{3}{*}{ I volunteered } & Count & 167 & 29 & 56 & 252 \\
\hline & & Expected Count & 158.2 & 33.4 & 60.3 & 252.0 \\
\hline & & Adjusted Residual & 2.7 & -1.9 & -1.5 & \\
\hline \multirow{2}{*}{\multicolumn{2}{|c|}{ Total }} & Count & 194 & 41 & 74 & 309 \\
\hline & & Expected Count & 194.0 & 41.0 & 74.0 & 309.0 \\
\hline
\end{tabular}

Chi-Square Tests

\begin{tabular}{|c|c|c|c|}
\hline & Value & df & $\begin{array}{c}\text { Asymp. Sig. } \\
\text { (2-sided) }\end{array}$ \\
\hline Pearson Chi-Square & $7.536(\mathrm{a})$ & 2 & .023 \\
\hline Likelihood Ratio & 7.240 & 2 & .027 \\
\hline $\begin{array}{c}\text { Linear-by-Linear } \\
\text { Association }\end{array}$ & 5.164 & 1 & .023 \\
\hline N of Valid Cases & 309 & & \\
\hline
\end{tabular}

(a) 0 cells (.0\%) have expected count less than 5 . The minimum expected count is 7.56. 
Bridges and Barriers to Teaching Online College Courses:

A Study of Experienced Online Faculty in Thirty-six Colleges

Table 55: Two-year and Four-year Faculty: A lack of recognition of online teaching in regards to tenure considerations.

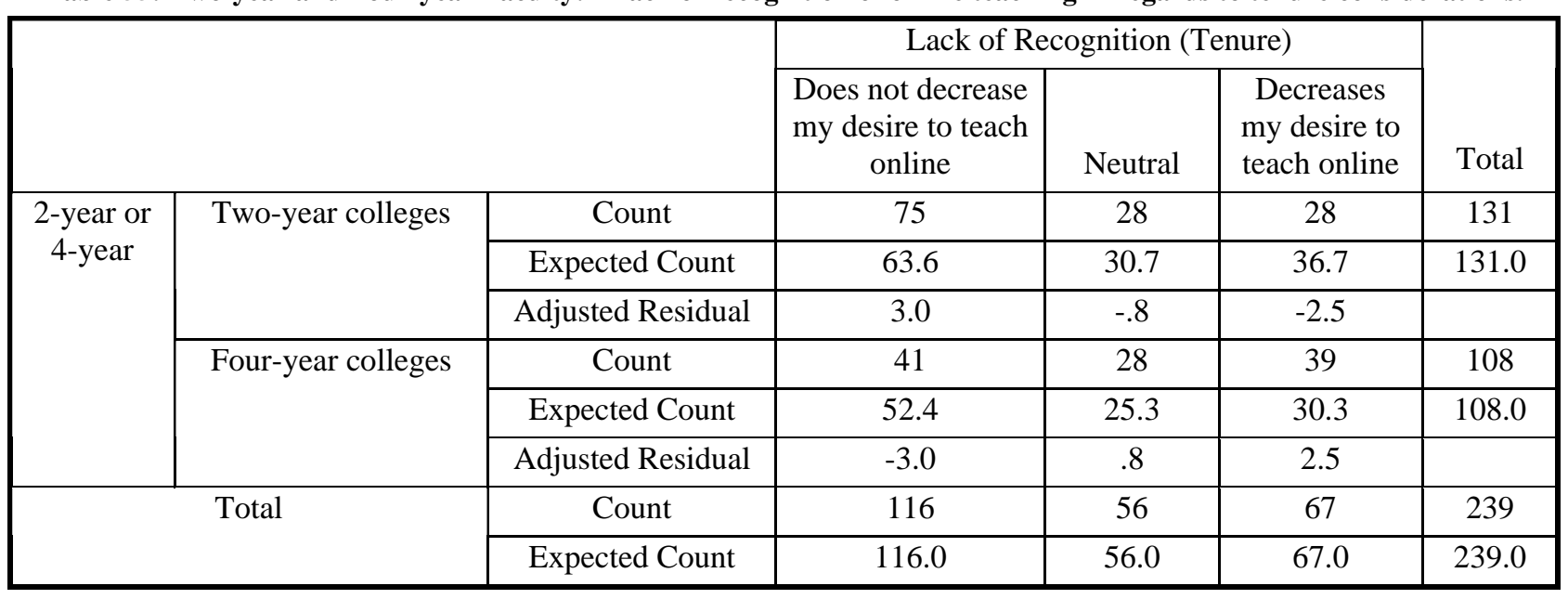

Chi-Square Tests

\begin{tabular}{|c|c|c|c|}
\hline & Value & df & $\begin{array}{c}\text { Asymp. Sig. } \\
\text { (2-sided) }\end{array}$ \\
\hline Pearson Chi-Square & $9.647(\mathrm{a})$ & 2 & .008 \\
\hline Likelihood Ratio & 9.711 & 2 & .008 \\
\hline $\begin{array}{c}\text { Linear-by-Linear } \\
\text { Association }\end{array}$ & 9.431 & 1 & .002 \\
\hline N of Valid Cases & 239 & & \\
\hline
\end{tabular}

(a) 0 cells (.0\%) have expected count less than 5 . The minimum expected count is 25.31 .

Table 56: Two-year and Four-year Faculty: The technology involved in online teaching can be confusing.

\begin{tabular}{|c|c|c|c|c|c|c|}
\hline & & & \multicolumn{3}{|c|}{ Confusing Technology } & \multirow[b]{2}{*}{ Total } \\
\hline & & & $\begin{array}{c}\text { Does not decrease } \\
\text { my desire to teach } \\
\text { online }\end{array}$ & Neutral & $\begin{array}{c}\text { Decreases } \\
\text { my desire to } \\
\text { teach online }\end{array}$ & \\
\hline \multirow{6}{*}{$\begin{array}{c}\text { 2-year or } \\
4 \text {-year }\end{array}$} & \multirow[t]{3}{*}{ Two-year colleges } & Count & 125 & 34 & 22 & 181 \\
\hline & & Expected Count & 117.8 & 27.6 & 35.5 & 181.0 \\
\hline & & Adjusted Residual & 1.7 & 2.0 & -3.8 & \\
\hline & \multirow[t]{3}{*}{ Four-year colleges } & Count & 84 & 15 & 41 & 140 \\
\hline & & Expected Count & 91.2 & 21.4 & 27.5 & 140.0 \\
\hline & & Adjusted Residual & -1.7 & -2.0 & 3.8 & \\
\hline \multirow{2}{*}{\multicolumn{2}{|c|}{ Total }} & Count & 209 & 49 & 63 & 321 \\
\hline & & Expected Count & 209.0 & 49.0 & 63.0 & 321.0 \\
\hline
\end{tabular}


Bridges and Barriers to Teaching Online College Courses:

A Study of Experienced Online Faculty in Thirty-six Colleges

Chi-Square Tests

\begin{tabular}{|c|c|c|c|}
\hline & Value & df & $\begin{array}{c}\text { Asymp. Sig. } \\
\text { (2-sided) }\end{array}$ \\
\hline Pearson Chi-Square & $16.168(\mathrm{a})$ & 2 & .000 \\
\hline Likelihood Ratio & 16.229 & 2 & .000 \\
\hline $\begin{array}{c}\text { Linear-by-Linear } \\
\text { Association }\end{array}$ & 8.429 & 1 & .004 \\
\hline N of Valid Cases & 321 & & \\
\hline
\end{tabular}

(a) 0 cells $(.0 \%)$ have expected count less than 5 . The minimum expected count is 21.37 .

Table 57: Two-year and Four-year Faculty: Inadequate time to revise online courses

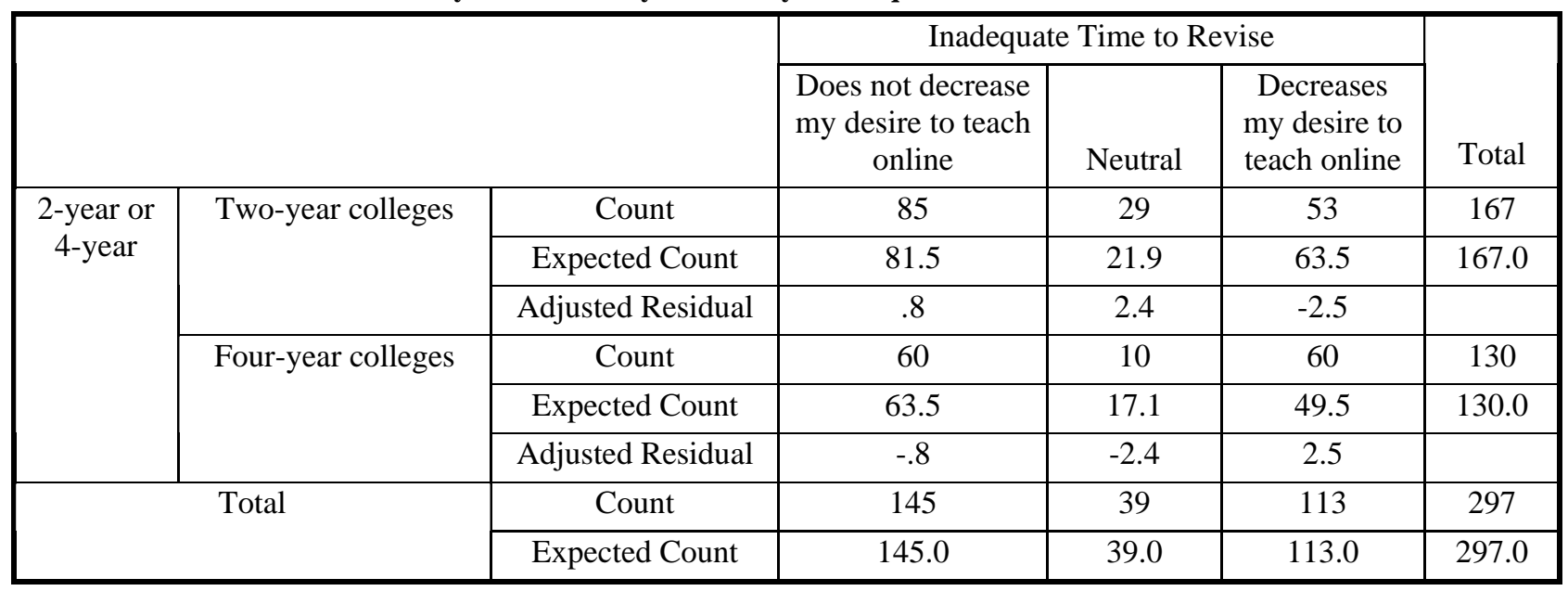

Chi-Square Tests

\begin{tabular}{|c|c|c|c|}
\hline & Value & $\mathrm{df}$ & $\begin{array}{c}\text { Asymp. Sig. } \\
\text { (2-sided) }\end{array}$ \\
\hline Pearson Chi-Square & $9.539(\mathrm{a})$ & 2 & .008 \\
\hline Likelihood Ratio & 9.807 & 2 & .007 \\
\hline $\begin{array}{c}\text { Linear-by-Linear } \\
\text { Association }\end{array}$ & 3.121 & 1 & .077 \\
\hline N of Valid Cases & 297 & & \\
\hline
\end{tabular}

(a) 0 cells (.0\%) have expected count less than 5 . The minimum expected count is 17.07 . 
Bridges and Barriers to Teaching Online College Courses:

A Study of Experienced Online Faculty in Thirty-six Colleges

Table 58: Computer Skill Level: There may be inadequate compensation for online course development.

\begin{tabular}{|c|c|c|c|c|c|c|}
\hline & & & \multicolumn{3}{|c|}{$\begin{array}{c}\text { Inadequate Compensation (Course } \\
\text { Development) }\end{array}$} & \multirow[b]{2}{*}{ Total } \\
\hline & & & $\begin{array}{l}\text { Does not decrease } \\
\text { my desire to teach } \\
\text { online }\end{array}$ & Neutral & $\begin{array}{c}\text { Decreases } \\
\text { my desire to } \\
\text { teach online }\end{array}$ & \\
\hline \multirow{9}{*}{$\begin{array}{l}\text { Computer } \\
\text { Skill }\end{array}$} & \multirow[t]{3}{*}{ Low } & Count & 8 & 9 & 7 & 24 \\
\hline & & Expected Count & 9.9 & 2.8 & 11.3 & 24.0 \\
\hline & & Adjusted Residual & -.8 & 4.1 & -1.8 & \\
\hline & \multirow[t]{3}{*}{ Medium } & Count & 59 & 13 & 63 & 135 \\
\hline & & Expected Count & 55.6 & 16.0 & 63.4 & 135.0 \\
\hline & & Adjusted Residual & .8 & -1.1 & -.1 & \\
\hline & \multirow[t]{3}{*}{ High } & Count & 55 & 13 & 69 & 137 \\
\hline & & Expected Count & 56.5 & 16.2 & 64.3 & 137.0 \\
\hline & & Adjusted Residual & -.3 & -1.2 & 1.1 & \\
\hline \multirow{2}{*}{\multicolumn{2}{|c|}{ Total }} & Count & 122 & 35 & 139 & 296 \\
\hline & & Expected Count & 122.0 & 35.0 & 139.0 & 296.0 \\
\hline
\end{tabular}

Chi-Square Tests

\begin{tabular}{|c|c|c|c|}
\hline & Value & df & $\begin{array}{c}\text { Asymp. Sig. } \\
\text { (2-sided) }\end{array}$ \\
\hline Pearson Chi-Square & $17.124(\mathrm{a})$ & 4 & .002 \\
\hline Likelihood Ratio & 12.547 & 4 & .014 \\
\hline $\begin{array}{c}\text { Linear-by-Linear } \\
\text { Association }\end{array}$ & .697 & 1 & .404 \\
\hline N of Valid Cases & 296 & & \\
\hline
\end{tabular}

(a) 1 cells $(11.1 \%)$ have expected count less than 5 . The minimum expected count is 2.84 .

Table 59: Computer Skill Level: The campus administration may not recognize the effort required to teach online.

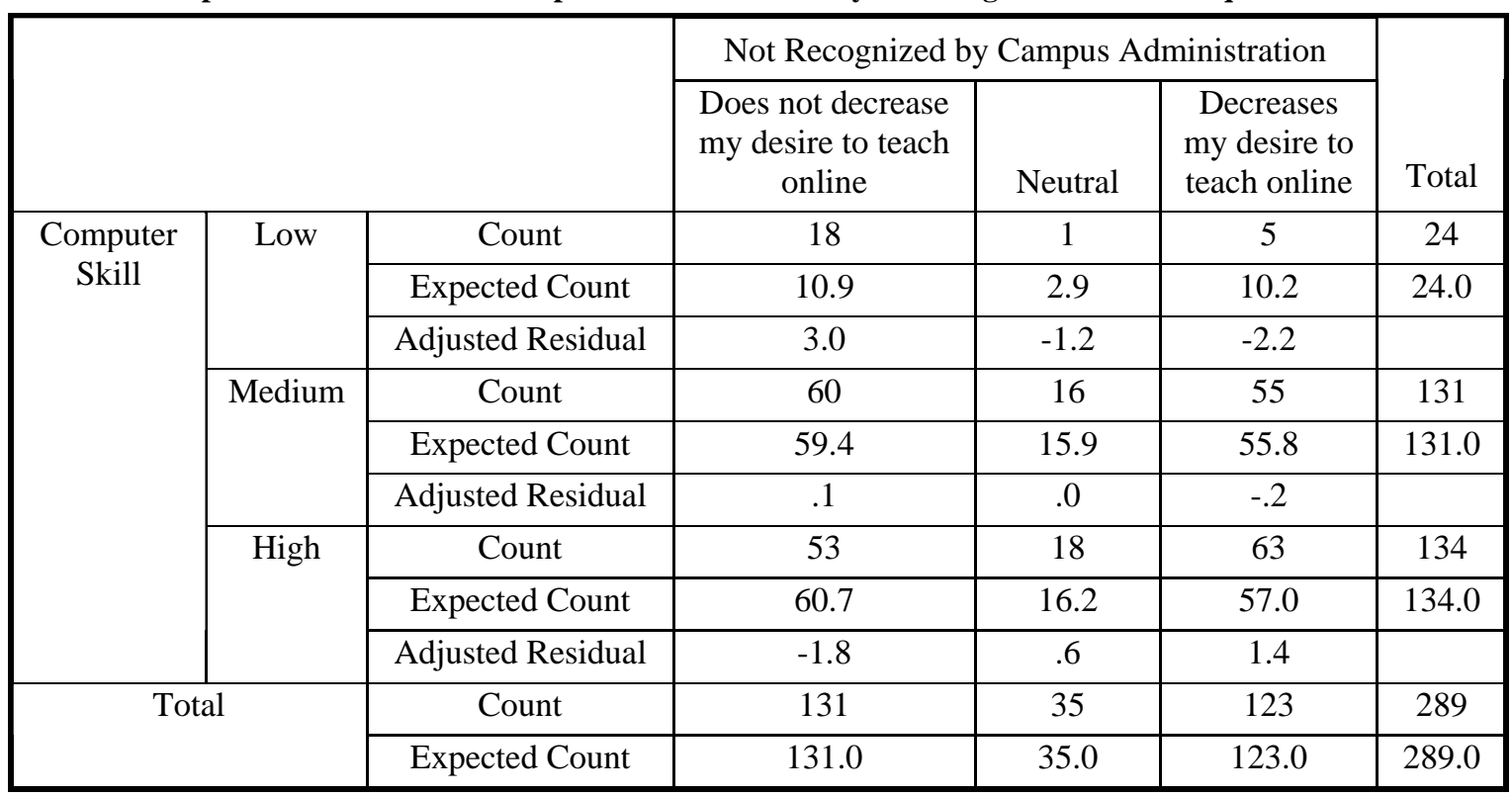


Bridges and Barriers to Teaching Online College Courses: A Study of Experienced Online Faculty in Thirty-six Colleges

Chi-Square Tests

\begin{tabular}{|c|c|c|c|}
\hline & Value & df & $\begin{array}{c}\text { Asymp. Sig. } \\
\text { (2-sided) }\end{array}$ \\
\hline Pearson Chi-Square & $10.396(\mathrm{a})$ & 4 & .034 \\
\hline Likelihood Ratio & 10.690 & 4 & .030 \\
\hline $\begin{array}{c}\text { Linear-by-Linear } \\
\text { Association }\end{array}$ & 6.629 & 1 & .010 \\
\hline N of Valid Cases & 289 & & \\
\hline
\end{tabular}

(a) 1 cells (11.1\%) have expected count less than 5 . The minimum expected count is 2.91 .

Table 60: Factor Pattern Matrix: Motivators

\begin{tabular}{|l|c|c|c|c|c|}
\hline & Learning & Profession & Flexibility & Access & Novelty \\
\hline Experiment with New Pedagogy & .763 & -.116 & -.216 & -.101 & -.123 \\
\hline Reflect and Think Classroom Teaching & .708 & -.011 & -.156 & -.112 & -.025 \\
\hline Gain New Knowledge & .684 & -.026 & -.144 & -.150 & -.163 \\
\hline Experiment with New Assessment. & .573 & .150 & -.154 & -.049 & -.163 \\
\hline High Level of Interaction & .503 & .102 & .164 & -.300 & -.053 \\
\hline Demonstrate Competencies & .041 & .654 & -.105 & .007 & .108 \\
\hline Employment & -.215 & .635 & -.106 & -.070 & -.043 \\
\hline Promote "Job Security." & .132 & .599 & -.103 & -.116 & .075 \\
\hline Positive Teaching & .122 & .570 & -.009 & -.166 & -.051 \\
\hline Collaborative Professional Development & .301 & .564 & .156 & .017 & -.268 \\
\hline Other Material Incentives & -.215 & .508 & -.122 & -.133 & -.181 \\
\hline Act as a Mentor & .398 & .494 & .104 & .018 & -.174 \\
\hline Teach a New Subject Area & -.060 & .465 & -.084 & -.112 & -.241 \\
\hline Students May Want Online Courses & .228 & .315 & -.094 & -.141 & -.094 \\
\hline Accommodates Other Life Needs & -.004 & .051 & -.760 & -.057 & -.099 \\
\hline Reduce commuting time or hassle & .025 & .146 & -.679 & -.095 & .053 \\
\hline Provides Flexible Teaching Environment & .167 & -.107 & -.671 & -.102 & -.152 \\
\hline Free Time & .120 & .293 & -.527 & .040 & -.011 \\
\hline Reach Students with Different Culture & -.021 & -.037 & -.041 & -.985 & .030 \\
\hline Reach Students with Different Location & .021 & -.017 & -.094 & -.895 & .044 \\
\hline Reach Students at Different Learning Stage & .052 & .092 &. .070 & -.754 & -.074 \\
\hline Learn New Technology & -.090 & -.058 & -.090 & -.030 & -.983 \\
\hline New Challenge & .205 & -.009 & -.121 & .004 & -.712 \\
\hline Renew Interest in Teaching & .215 & .160 & .111 & -.103 & -.476 \\
\hline Reliability (overall .94) & .87 & .88 & .85 & .91 & .78 \\
\hline
\end{tabular}


Bridges and Barriers to Teaching Online College Courses:

A Study of Experienced Online Faculty in Thirty-six Colleges

Table 61: Factor Pattern Matrix: Demotivators

\begin{tabular}{|c|c|c|c|c|c|}
\hline & Compensation & Reputation & Complexity & Promotion & Technology \\
\hline $\begin{array}{l}\text { Inadequate Compensation (Course } \\
\text { Development) }\end{array}$ & .904 & .046 & .028 & .024 & .043 \\
\hline Inadequate Compensation (Teaching) & .890 & .013 & -.023 & .067 & -.036 \\
\hline Inadequate Compensation (Revision) & .887 & .020 & .084 & .045 & .049 \\
\hline $\begin{array}{l}\text { Inadequate Time to Develop A New Online } \\
\text { Course }\end{array}$ & .637 & -.021 & .041 & .001 & -.353 \\
\hline Inadequate Time to Revise & .572 & .015 & .065 & -.016 & -.417 \\
\hline Inadequate Time to Learn & .436 & .047 & .087 & .048 & -.453 \\
\hline More Time & .427 & .200 & .254 & -.002 & -.071 \\
\hline Intellectual Property and Teaching Online & .335 & .177 & .099 & .028 & -.236 \\
\hline Negative Comment from Colleague & -.033 & .852 & .120 & -.033 & .004 \\
\hline Negative comments about Inferior Quality & .061 & .834 & .088 & .070 & .129 \\
\hline Reduce Institution's Reputation. & .039 & .783 & .074 & -.058 & -.036 \\
\hline Not valued by Campus Administration & .120 & .716 & -.080 & .164 & -.025 \\
\hline Students Don't Want Online Course & -.080 & .604 & -.044 & .030 & -.177 \\
\hline Not Recognized by Campus Administration & .435 & .558 & -.053 & .123 & .148 \\
\hline Complicated Course Development & .042 & -.059 & .841 & .151 & .106 \\
\hline Confusing Technology & -.005 & -.022 & .733 & .134 & -.083 \\
\hline Unfamiliar Effective Pedagogy & -.011 & .119 & .707 & .032 & .027 \\
\hline Absence of Face-to-Face Interaction & .054 & .028 & .622 & -.129 & -.078 \\
\hline $\begin{array}{l}\text { Qpolicies_A_2 Lack of Recognition (Salary } \\
\text { Increment) }\end{array}$ & .028 & -.007 & .002 & .924 & -.019 \\
\hline $\begin{array}{l}\text { Qpolicies_A_1 Lack of Recognition } \\
\text { (Tenure) }\end{array}$ & -.041 & .042 & .089 & .882 & -.054 \\
\hline $\begin{array}{l}\text { Qtechsuppissues_A_2 Inadequate Technical } \\
\text { Support on Teaching }\end{array}$ & .092 & .049 & -.009 & .110 & -.789 \\
\hline $\begin{array}{l}\text { Qtechsuppissues_A_1 Inadequate Technical } \\
\text { Support on Course Development }\end{array}$ & .138 & .008 & -.012 & .127 & -.777 \\
\hline $\begin{array}{l}\text { Qtechsuppissues_A_3 Students Lack } \\
\text { Adequate Access }\end{array}$ & -.010 & .159 & .287 & -.005 & -.498 \\
\hline $\begin{array}{l}\text { Qtechsuppissues_A_5 No Opportunity to } \\
\text { Experiment with Technology }\end{array}$ & .125 & .186 & .273 & .004 & -.465 \\
\hline $\begin{array}{l}\text { Qtechsuppissues_A_4 Little or No } \\
\text { Opportunity to Observe }\end{array}$ & -.025 & .325 & .245 & .032 & -.462 \\
\hline Reliability (overall .96) & .93 & .91 & .83 & .95 & .92 \\
\hline
\end{tabular}

